\title{
Unsymmetrically Substituted 9,10-Dihydro-9,10-diboraanthracenes as Versatile Building Blocks for Boron-Doped $\pi$-Conjugated Systems
}

\author{
Estera Januszewski, ${ }^{[a]}$ Andreas Lorbach, ${ }^{[a]}$ Rekha Grewal, ${ }^{[a]}$ Michael Bolte, ${ }^{[a]}$ \\ Jan W. Bats, ${ }^{[b]}$ Hans-Wolfram Lerner, ${ }^{[a]}$ and Matthias Wagner*[a]
}

\begin{abstract}
The targeted hydrolysis of the 9,10-dihydro-9,10-diboraanthracene adduct $\left(\mathrm{Me}_{2} \mathrm{~S}\right) \mathrm{HB}\left(\mathrm{C}_{6} \mathrm{H}_{4}\right)_{2} \mathrm{BH}\left(\mathrm{SMe}_{2}\right)$ (1) with 0.5 equiv of $\mathrm{H}_{2} \mathrm{O}$ leads to formation of the borinic acid anhydride $\left[\left(\mathrm{Me}_{2} \mathrm{~S}\right) \mathrm{HB}\left(\mathrm{C}_{6} \mathrm{H}_{4}\right)_{2} \mathrm{~B}\right]_{2} \mathrm{O}(2)$ and thereby provides access to the field of unsymmetrically substituted 9,10-dihydro9,10-diboraanthracenes. Compound 2 reacts with $t \mathrm{BuC} \equiv \mathrm{CH}$ to give the corresponding vinyl derivative in an essentially quantitative conversion. Subsequent cleavage of the B-O-B bridge by $\mathrm{LiAlH}_{4}$ with formation of hydridoborate functionalities is possible but is accompanied by partial $\mathrm{B}-\mathrm{C}$ (vinyl) bond degradation. This situation changes
\end{abstract}

when the related mesityl derivative $\left[\mathrm{MesB}\left(\mathrm{C}_{6} \mathrm{H}_{4}\right)_{2} \mathrm{~B}\right]_{2} \mathrm{O} \quad$ (7) is employed, which can be synthesized from BrB$\left(\mathrm{C}_{6} \mathrm{H}_{4}\right)_{2} \mathrm{BBr}$ (6) by treatment with 1 equiv of $\mathrm{MesMgBr}$ and subsequent hydrolysis. The reaction of $\mathbf{7}$ with $\mathrm{LiAlH}_{4}$ in tetrahydrofuran (THF) furnishes $\mathrm{Li}\left[\mathrm{MesB}\left(\mathrm{C}_{6} \mathrm{H}_{4}\right)_{2} \mathrm{BH}_{2}\right] \quad(8)$; hydride elimination with $\mathrm{Me}_{3} \mathrm{SiCl}$ leads to formation of the THF adduct MesB$\left(\mathrm{C}_{6} \mathrm{H}_{4}\right)_{2} \mathrm{BH}(\mathrm{THF})$ (9.THF). Alternatively, 7 can be transformed into the bromoborane $\mathrm{MesB}\left(\mathrm{C}_{6} \mathrm{H}_{4}\right)_{2} \mathrm{BBr}(\mathbf{1 0})$ by treatment with $\mathrm{BBr}_{3}$. A Br/H-exchange reaction between $\mathbf{1 0}$ and $\mathrm{Et}_{3} \mathrm{SiH}$ yields the donor-free borane $\mathrm{MesB}\left(\mathrm{C}_{6} \mathrm{H}_{4}\right)_{2} \mathrm{BH}$ (9), which forms B-H-B bridged dimers $(9)_{2}$ in the solid state. The vinyl borane $\operatorname{MesB}\left(\mathrm{C}_{6} \mathrm{H}_{4}\right)_{2} \mathrm{BC}(\mathrm{H})=\mathrm{C}(\mathrm{H}) \mathrm{Mes} \quad(\mathbf{1 4})$ is accessible from $\mathrm{Mes} \mathrm{C} \equiv \mathrm{CH}$ and either 9.THF or 9. Compared with the related compound $\mathrm{Mes}_{2} \mathrm{BC}(\mathrm{H})=\mathrm{C}(\mathrm{H}) \mathrm{Mes}$, the electronic absorption and emission spectra of $\mathbf{1 4}$ reveal bathochromic shifts of $\Delta \lambda(\mathrm{abs})=17 \mathrm{~nm}$ and $\Delta \lambda(\mathrm{em})=$ $74 \mathrm{~nm}$, which can be attributed to the rigid, fully delocalized $\pi$ framework of the $\left[\mathrm{MesB}\left(\mathrm{C}_{6} \mathrm{H}_{4}\right)_{2} \mathrm{~B}\right]$ chromophore.

\section{Introduction}

The incorporation of three-coordinate boron atoms into conjugated $\pi$-electron frameworks leads to changes in the electronic structure that often bring about enhanced luminescence and charge-transport properties. ${ }^{[1-4]}$ Moreover, the ability of boron atoms to form Lewis acid-base pairs and thereby to disrupt the $\pi$-conjugation pathway can be exploit-

[a] Dipl.-Chem. E. Januszewski, Dr. A. Lorbach, B. Sc. R. Grewal, Dr. M. Bolte, Dr. H.-W. Lerner, Prof. Dr. M. Wagner

Institut für Anorganische und Analytische Chemie

Goethe-Universität Frankfurt

Max-von-Laue-Straße 7, 60438 Frankfurt am Main (Germany)

Fax: (+49)69-798-29260

E-mail: Matthias.Wagner@chemie.uni-frankfurt.de

[b] Dr. J. W. Bats

Institut für Organische Chemie, Goethe-Universität Frankfurt, Max-von-Laue-Straße 7, 60438 Frankfurt am Main (Germany) ed for the development of molecular switches and sensors. $^{[4-7]}$

However, the propensity of organoboranes to react with Lewis bases is also a disadvantage, because it renders the compounds intrinsically sensitive to air and moisture. The vast majority of organoboranes employed in materials science and sensor technology therefore contain at least one, in many cases two, bulky substituents for kinetic stabilization (cf. the popular di(mesityl)boryl group) ${ }^{[8]}$ Even though the concept of steric protection has already furnished a variety of remarkable organoboranes that can be handled in air and purified by chromatography on silica gel, it nevertheless suffers from certain disadvantages: 1) The size of any analyte that can be detected by the corresponding organoborane sensors is very limited (for example, $\mathrm{F}^{-}, \mathrm{CN}^{-}$). 2) A di(mesityl)boryl group with its single free valence can only act as a peripheral substituent, and not become an integral part of the $\pi$-electron system. 3) Steric congestion in triarylboranes leads to twisting of the aryl substituents about the $\mathrm{B}-\mathrm{C}$ bonds and thereby to decreased $\pi$ conjugation across the boron center. Thus, attachment of a di(mesityl)boryl group merely adds one vacant boron-centered p-orbital to the $\pi$ electron cloud, whereas the two mesityl rings remain more or less spectator groups.

For the design of building blocks other than di(mesityl)borane, we considered that 1) the building block itself should already possess an extended $\pi$-conjugated elec- 
tron system; 2) a rigid planar framework would guarantee maximum $\pi$ overlap between the boron atoms and the aromatic substituents; 3) a cyclic structure should be most stable. All these requirements are met by the 9,10-dihydro9,10-diboraanthracene framework, which can be integrated into $\pi$-electron systems either by nucleophilic substitution (cf. starting material A; Scheme 1) or by hydroboration re-

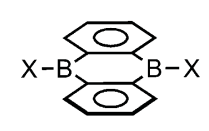

A

$\mathrm{X}=\mathrm{Cl}, \mathrm{Br}$
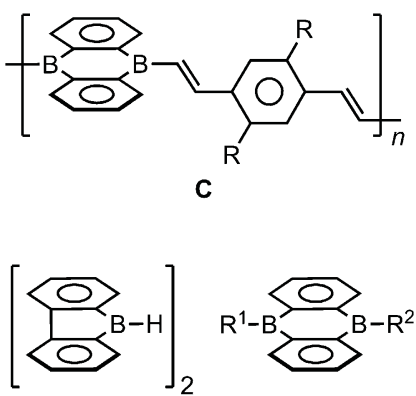

$(\mathrm{D})_{2}$

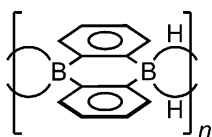

$(\mathbf{B})_{n}$

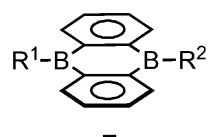

E
Scheme 1. Symmetrically substituted 9,10-dihydro-9,10-diboraanthracenes $\mathbf{A}$ and $\mathbf{B}$; polymers $\mathbf{C}$ obtained by hydroboration polymerization of aromatic dialkynes with $\mathbf{B}(\mathrm{R}=\mathrm{H}, \mathrm{OHex})$; $9 H$-9-borafluorene $\mathbf{D}$, which is a monotopic relative of $\mathbf{B}$; unsymmetrically substituted 9,10-dihydro-9,10diboraanthracenes $\mathbf{E}$.

actions (cf. starting material $\mathbf{B}$; Scheme 1). 9,10-Dihalo-9,10dihydro-9,10-diboraanthracenes $\mathbf{A}$ have been extensively reported in the literature $\left(\mathrm{X}=\mathrm{Cl},{ }^{[9,10]} \mathrm{Br} ;{ }^{[9,11,12]}\right.$ for optimized synthesis protocols, a comprehensive compilation of NMR data, and X-ray crystal structure analyses see the Supporting Information of this paper). In contrast, the parent compound $\mathbf{B}$ has only recently been described. ${ }^{[13]}$ Compound $\mathbf{B}$, which forms a B-H-B bridged polymer $(\mathbf{B})_{n}$ in the solid state, can be used for hydroboration polymerization reactions (cf. product $\mathbf{C}$; Scheme 1$)^{[13]}$ either directly or after conversion into the more soluble dimethyl sulfide adduct (1; Scheme 2). ${ }^{[14]}$ Polymer $\mathbf{C}$ exhibits green photoluminescence, and various low molecular-weight analogues $\mathrm{RC}(\mathrm{H})=$ $\mathrm{C}(\mathrm{H}) \mathrm{B}\left(\mathrm{C}_{6} \mathrm{H}_{4}\right)_{2} \mathrm{BC}(\mathrm{H})=\mathrm{C}(\mathrm{H}) \mathrm{R}$ are also strongly emissive. ${ }^{[15]}$ Moreover, appropriately designed 9,10-dihydro-9,10-diboraanthracenes (including B) act as reversible two-electron acceptors, the dianionic form being isoelectronic with anthracene. ${ }^{[16]}$ Due to these remarkable optoelectronic properties, the entire class of compounds is very promising for applications in organic solar cells (OSCs) or light-emitting devices (OLEDs).

To gain a deeper understanding of the optoelectronic properties of polymers of type $\mathbf{C}$, it is desirable to have facile access to well-defined smaller model systems. We have already tested $9 \mathrm{H}$-9-borafluorene $(\mathbf{D}$; Scheme 1$)$ as a truncated monotopic analogue of the ditopic 9,10-dihydro-

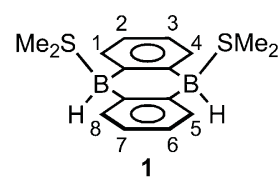

(i)

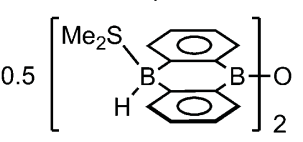

2
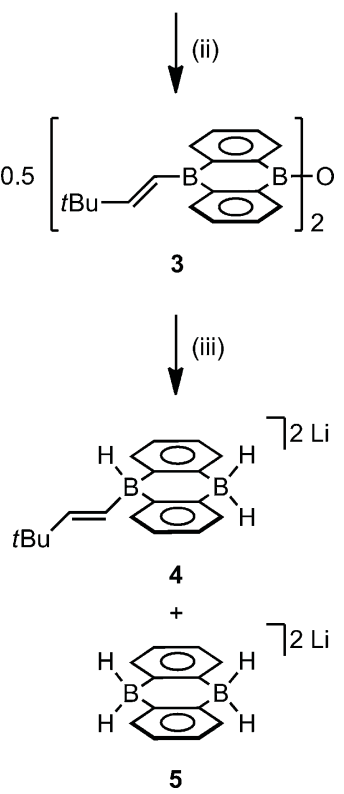

Scheme 2. Synthesis of compounds 2-5. Reagents and conditions: i) $\mathrm{H}_{2} \mathrm{O}$ ( 0.5 equiv), $\mathrm{THF} / \mathrm{Me}_{2} \mathrm{~S}$, room temperature; ii) $t \mathrm{BuC} \equiv \mathrm{CH}$ (excess), $\mathrm{C}_{6} \mathrm{D}_{6}$ room temperature; iii) $\mathrm{LiAlH}_{4}$ (excess), $\left[\mathrm{D}_{8}\right] \mathrm{THF}$, room temperature.

9,10-diboraanthracene B. Compound D, which adopts a unique phenyl-bridged dimeric structure $(\mathbf{D})_{2}$, is not stable in solution over the long-term, but readily undergoes a ringopening oligomerization reaction. ${ }^{[17]}$ Nevertheless, provided that freshly prepared samples of the compound are immediately used for further conversions, $\mathbf{D}$ is a valuable hydroboration reagent.

DFT calculations indicate that the ring-opening polymerization (ROP) of $\mathbf{D}$ is largely driven by the loss of antiaromaticity in the central borole ring. ${ }^{[17]}$ Monomeric 9,10-dihydro-9,10-diboraanthracene also possesses a formally antiaromatic central six-membered ring, but shows no tendency toward the ROP reaction. This observation, among others, led us to the conclusion that the electronic structure of $9 \mathrm{H}$ 9-borafluorene is still too dissimilar to that of 9,10-dihydro9,10-diboraanthracene to regard the former as a well-designed end cap of low molecular-weight analogues of polymers $\mathbf{C}$.

Herein, we describe protocols for the scalable generation of unsymmetrically substituted 9,10-dihydro-9,10-diboraanthracenes $\mathbf{E}$ (Scheme 1) in which one boron atom is pro- 
tected by a comparatively inert group, whereas the second boron atom bears a reactive substituent (for example, $\mathrm{R}^{1}=$ $\mathrm{OR}, \mathrm{Mes} ; \mathrm{R}^{2}=\mathrm{H}, \mathrm{Br} ;$ Mes $=$ mesityl).

\section{Results and Discussion}

A potentially viable six-step route to compounds of type $\mathbf{E}$ has recently been published by Kawashima et al. ${ }^{[18]}$ However, the only 9,10-dihydro-9,10-diboraanthracene isolated was the symmetrically substituted molecule $\operatorname{MesB}\left(\mathrm{C}_{6} \mathrm{H}_{4}\right)_{2} \mathrm{BMes}$. Described below are therefore the first examples of derivatives $\mathbf{E}$ with $\mathrm{R}^{1} \neq \mathrm{R}^{2}$, together with reactivity studies and a comparison of the electronic spectra of MesB$\left(\mathrm{C}_{6} \mathrm{H}_{4}\right)_{2} \mathrm{BC}(\mathrm{H})=\mathrm{C}(\mathrm{H}) \mathrm{Mes}$ and $\mathrm{Mes}_{2} \mathrm{BC}(\mathrm{H})=\mathrm{C}(\mathrm{H}) \mathrm{Mes}$.

Symmetry breaking by targeted hydrolysis: During investigations into the hydrolytic stability of the ditopic borane adduct 1 (Scheme 2), ${ }^{[14]}$ we observed the ready formation of borinic acid anhydride $\mathbf{2}$ (Scheme 2), which could be separated from residual $\mathbf{1}$ by fractional crystallization from $\mathrm{SMe}_{2}$. Optimized yields of close to $50 \%$ were obtained when 0.5 equiv of $\mathrm{H}_{2} \mathrm{O}$ were employed.

An X-ray crystal structure analysis of 2 revealed that the compound contains two unsymmetrically substituted 9,10-dihydro-9,10-diboraanthracene moieties (Figure 1; Table 1).

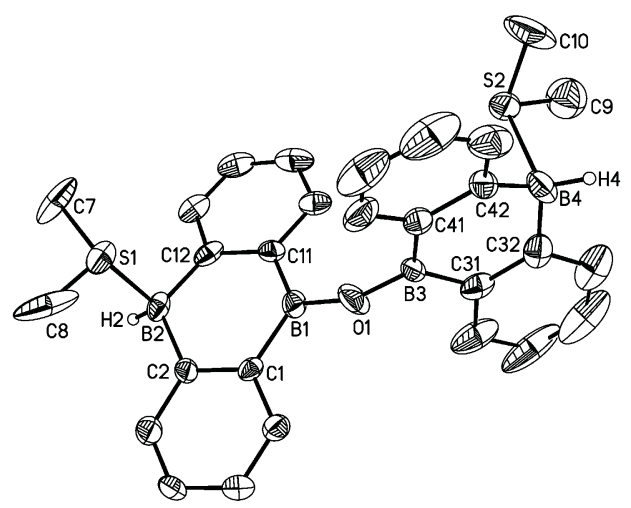

Figure 1. Molecular structure of $\mathbf{2}$ in the solid state (for $\mathrm{S}(2) \mathrm{Me}_{2}$ only the major occupied site is shown); displacement ellipsoids at the $30 \%$ probability level, $\mathrm{H}$ atoms (except on boron) omitted for clarity. Selected bond lengths $[\AA]$, bond angles $\left[{ }^{\circ}\right]$, and dihedral angle $\left[{ }^{\circ}\right]$ : B1-O1 1.345(7), B3O1 1.337(7), B2-S1 2.029(6), B4-S2 2.073(8); B1-O1-B3 156.5(5), S1-B2C2 104.1(4), S1-B2-C12 101.6(3), S2-B4-C32 104.9(5), S2-B4-C42 96.8(5); C1-B1-C11//C31-B3-C41 89.6(5)

The B-O-B bridge possesses an average bond length (BO) $)_{\text {av }}$ of 1.341(7) $\AA$, the B-O-B bond angle amounts to $156.5(5)^{\circ}$. These metrical parameters are in good agreement with the corresponding values for one of the two known polymorphs of diphenylborinic acid anhydride $\left((\mathrm{B}-\mathrm{O})_{\mathrm{av}}=\right.$ 1.346(4) $\AA$; $\left.\mathrm{B}-\mathrm{O}-\mathrm{B}=152.7(2)^{\circ}\right){ }^{[19]}$ The second polymorph, however, exhibits significantly longer $\mathrm{B}-\mathrm{O}$ bonds $((\mathrm{B}-$ $\left.\mathrm{O})_{\mathrm{av}}=1.370(3) \AA\right)$, together with a narrower B-O-B angle $\left(147.3(2)^{\circ}\right) \cdot{ }^{[20]}$ Given that the packing motifs of the two polymorphs of diphenylborinic acid anhydride are quite differ-
Table 1. Crystallographic data for $\mathbf{2 ,} \mathbf{7}$, and $\mathbf{1 0}$.

\begin{tabular}{|c|c|c|c|}
\hline & 2 & 7 & 10 \\
\hline formula & $\mathrm{C}_{28} \mathrm{H}_{30} \mathrm{~B}_{4} \mathrm{OS}_{2}$ & $\mathrm{C}_{42} \mathrm{H}_{38} \mathrm{~B}_{4} \mathrm{O}$ & $\mathrm{C}_{21} \mathrm{H}_{19} \mathrm{~B}_{2} \mathrm{Br}$ \\
\hline$M_{\mathrm{r}}$ & 489.88 & 601.96 & 372.89 \\
\hline color, shape & colorless, block & colorless, plate & yellow, plate \\
\hline$T[\mathrm{~K}]$ & $173(2)$ & $173(2)$ & $173(2)$ \\
\hline radiation, $\lambda[\AA]$ & $\mathrm{Mo}_{\mathrm{K} \alpha}, 0.71073$ & $\mathrm{Mo}_{\mathrm{Ka}}, 0.71073$ & $\mathrm{Mo}_{\mathrm{Ka}}, 0.71073$ \\
\hline crystal system & orthorhombic & triclinic & monoclinic \\
\hline space group & $P 2_{1} 2_{1} 2_{1}$ & $P \overline{1}$ & $P 2_{1} / c$ \\
\hline$a[\AA]$ & $9.6827(10)$ & $8.8596(18)$ & $15.0527(15)$ \\
\hline$b[\AA]$ & $15.4538(10)$ & $11.720(2)$ & $8.1450(6)$ \\
\hline$c[\AA]$ & $18.1279(11)$ & $17.288(4)$ & $14.8148(18)$ \\
\hline$\alpha\left[^{\circ}\right]$ & 90 & $93.33(3)$ & 90 \\
\hline$\beta\left[^{\circ}\right]$ & 90 & $98.44(3)$ & $93.863(9)$ \\
\hline$\gamma\left[^{\circ}\right]$ & 90 & $100.29(3)$ & 90 \\
\hline$V\left[\AA^{3}\right]$ & $2712.6(4)$ & $1740.5(7)$ & $1812.2(3)$ \\
\hline$Z$ & 4 & 2 & 4 \\
\hline$\rho_{\text {calcd }}\left[\mathrm{g} \mathrm{cm}^{-3}\right]$ & 1.200 & 1.149 & 1.367 \\
\hline $\mathrm{F}(000)$ & 1032 & 636 & 760 \\
\hline$\mu\left[\mathrm{mm}^{-1}\right]$ & 0.216 & 0.065 & 2.266 \\
\hline crystal size $[\mathrm{mm}]$ & $0.35 \times 0.34 \times 0.27$ & $0.27 \times 0.24 \times 0.11$ & $0.27 \times 0.25 \times 0.13$ \\
\hline reflections collected & 28017 & 13930 & 7395 \\
\hline $\begin{array}{l}\text { independent reflec- } \\
\text { tions }\left(R_{\text {int }}\right)\end{array}$ & $5238(0.1155)$ & $6462(0.0899)$ & $3187(0.0741)$ \\
\hline $\begin{array}{l}\text { data/restraints/pa- } \\
\text { rameters }\end{array}$ & $5238 / 0 / 325$ & $6462 / 0 / 430$ & $3187 / 0 / 220$ \\
\hline GOF on $F^{2}$ & 0.986 & 0.807 & 0.923 \\
\hline$R_{1}, w R_{2}[I>2 \sigma(I)]$ & $0.0829,0.2005$ & $0.0515,0.0954$ & $0.0521,0.1101$ \\
\hline$R_{1}, w R_{2}$ (all data) & $0.1318,0.2289$ & $0.1259,0.1108$ & $0.0832,0.1187$ \\
\hline $\begin{array}{l}\text { largest diff peak } \\
\text { and hole }\left[\mathrm{e} \AA^{-3}\right]\end{array}$ & $0.565,-0.445$ & $0.176,-0.193$ & $0.907,-0.676$ \\
\hline
\end{tabular}

ent, we conclude that B-O-B deformation is associated with a shallow potential well so that the bond lengths and the bond angle are easily influenced by crystal packing forces. As can be expected for a heteroallene derivative, we find a perpendicular arrangement of the two $\mathrm{BR}_{2}$ planes in 2 (cf. $\left.\mathrm{C} 1-\mathrm{B} 1-\mathrm{C} 11 / / \mathrm{C} 31-\mathrm{B} 3-\mathrm{C} 41=89.6(5)^{\circ}\right)$.

All key bond lengths and angles involving the four-coordinate boron atoms of $\mathbf{2}$ are similar to those in the starting material and are therefore not discussed further.

The ${ }^{11} \mathrm{~B}$ NMR spectrum $\left(\mathrm{C}_{6} \mathrm{D}_{6}\right)$ of $\mathbf{2}$ is characterized by two resonances at $\delta=-3.0\left(B(\mathrm{H}) \mathrm{SMe}_{2}\right)$ and $43.2 \mathrm{ppm}(B \mathrm{O})$. Thus, the three-coordinate boron atoms possess almost the same chemical shift values as those of diphenylborinic acid anhydride $\left(\delta\left({ }^{11} \mathrm{~B}\right)=46.1 \mathrm{ppm}^{[19]}\right)$, whereas the four-coordinate boron centers are much better shielded in the hydrolysis product 2 than in the starting material $\mathbf{1}\left(\delta\left({ }^{11} \mathrm{~B}\right)=\right.$ $\left.28.1 \mathrm{ppm}^{[14]}\right)$. In both cases, the ${ }^{1} J(\mathrm{~B}, \mathrm{H})$ coupling is not resolved, but broad resonances for the boron-bound hydrogen atoms are detectable in the ${ }^{1} \mathrm{H}$ NMR spectra. In line with the different substituents at the peripheral and internal boron atoms, the four phenylene rings give rise to two apparent triplets and two doublets in the ${ }^{1} \mathrm{H}$ NMR spectrum, and to four resonances in the ${ }^{13} \mathrm{C}$ NMR spectrum (signals of carbon atoms attached to boron were not detected due to unresolved ${ }^{1} J(\mathrm{~B}, \mathrm{C})$ coupling and quadrupolar broadening $\left.^{[21]}\right)$.

Exploratory investigations into the reactivity of $\mathbf{2}$ were undertaken on an NMR scale. First, the compound was treated in $\mathrm{C}_{6} \mathrm{D}_{6}$ with a tenfold excess of $t \mathrm{BuC} \equiv \mathrm{CH}$. After 
30 min at room temperature, ${ }^{1} \mathrm{H}$ NMR spectroscopic analysis revealed an essentially quantitative conversion into the divinyl borane 3 (Scheme 2), as evidenced by the presence of two doublets at $\delta=6.66$ and $7.01 \mathrm{ppm}(2 \times 2 \mathrm{H})$ with a ${ }^{3} J$ $(\mathrm{H}, \mathrm{H})$ coupling constant of $18.2 \mathrm{~Hz}$, which is typical of $E$ olefins (see the Supporting Information). The related hydroboration product of $\mathbf{1}, t \mathrm{BuC}(\mathrm{H})=\mathrm{C}(\mathrm{H}) \mathrm{B}\left(\mathrm{C}_{6} \mathrm{H}_{4}\right)_{2} \mathrm{BC}(\mathrm{H})=$ $\mathrm{C}(\mathrm{H}) t \mathrm{Bu}$, shows vinyl resonances at $\delta\left({ }^{1} \mathrm{H}\right)=6.74$ and $6.99 \mathrm{ppm}\left({ }^{3} J(\mathrm{H}, \mathrm{H})=18.1 \mathrm{~Hz}\right) \cdot{ }^{[13,14]}$ We conclude that 2 represents a versatile building block for the generation of other unsymmetrically substituted 9,10-dihydro-9,10-diboraanthracenes, because its two HB functionalities can readily be used in hydroboration reactions.

Further derivatization of $\mathbf{3}$ at its B-O-B bridge was attempted by the reaction with excess $\mathrm{LiAlH}_{4}$ in $\left[\mathrm{D}_{8}\right] \mathrm{THF}$ (see the Supporting Information). In situ ${ }^{11} \mathrm{~B}$ NMR spectroscopy revealed a triplet resonance at $\delta=-16.0 \mathrm{ppm} \quad\left({ }^{1} J\right.$ $(\mathrm{B}, \mathrm{H})=76 \mathrm{~Hz})$ and a doublet at $\delta=-11.1 \mathrm{ppm}\left({ }^{1} J(\mathrm{~B}, \mathrm{H})=\right.$ $60 \mathrm{~Hz}$ ), which points toward a reaction product possessing two chemically different four-coordinate boron centers, $\mathrm{H}_{2} \mathrm{BR}_{2}$ and $\mathrm{HBR}_{3}$, respectively. In the ${ }^{1} \mathrm{H} \mathrm{NMR}$ spectrum, vinyl resonances were present at $\delta=5.63(1 \mathrm{H})$ and $5.89 \mathrm{ppm}$ $(1 \mathrm{H})$; the latter signal showed fine splitting due to ${ }^{3} \mathrm{~J}(\mathrm{H}, \mathrm{H})$ coupling with one $\mathrm{BH}$ hydrogen atom. The phenylene resonances appeared as complex overlapping multiplets at $\delta=$ $6.58(4 \mathrm{H})$ and $7.24 \mathrm{ppm}(4 \mathrm{H})$. We therefore propose that the B-O-B bridge has indeed been cleaved, with formation of the unsymmetrical hydridoborate 4 (Scheme 2). However, it has so far not been possible to develop a fully selective synthetic protocol because the symmetrical hydridoborate $\mathrm{Li}_{2}\left[\mathrm{H}_{2} \mathrm{~B}\left(\mathrm{C}_{6} \mathrm{H}_{4}\right)_{2} \mathrm{BH}_{2}\right](5)$ is always generated as a byproduct (at least $15 \%$ ). Compound $\mathbf{5}$ was identified by comparison of its NMR data with those of an authentic sample prepared from $\mathrm{HOB}\left(\mathrm{C}_{6} \mathrm{H}_{4}\right)_{2} \mathrm{BOH}$ and $\mathrm{LiAlH}_{4}$ (see the Supporting Information for more information and an X-ray crystal structure analysis of the borinic acid).

Symmetry breaking by nucleophilic substitution: Our experiences with the system $3 / \mathrm{LiAlH}_{4}$ indicate that, in principle, such borinic acid anhydrides are useful precursors for the synthesis of unsymmetrically substituted 9,10-dihydro-9,10diboraanthracenes, but that the $\mathrm{B}-\mathrm{C}$ (vinyl) bond is too fragile to persist under the reaction conditions applied. We therefore decided to replace the tert-butylvinyl substituents in $\mathbf{3}$ by more robust mesityl groups and to explore the reactivity of the resulting compound 7 (Scheme 3 ).

Preferential monosubstitution of $\mathrm{BrB}\left(\mathrm{C}_{6} \mathrm{H}_{4}\right)_{2} \mathrm{BBr}(6)^{[22]}$ is feasible with $\mathrm{MesMgBr}^{[23]}$ in toluene provided that high dilution is maintained. Nevertheless, $\operatorname{MesB}\left(\mathrm{C}_{6} \mathrm{H}_{4}\right)_{2} \mathrm{BBr}$ obtained this way was always contaminated with the disubstitution product $\mathrm{MesB}\left(\mathrm{C}_{6} \mathrm{H}_{4}\right)_{2} \mathrm{BMes}$ and was not readily isolable in pure form. It therefore turned out to be convenient to quench the reaction with $\mathrm{H}_{2} \mathrm{O}$, thereby generating the borinic acid anhydride 7, which could subsequently be purified by column chromatography (yield: $76 \%$; note: in the presence of $\mathrm{H}_{2} \mathrm{O}, 7$ is in equilibrium with the borinic acid MesB$\left(\mathrm{C}_{6} \mathrm{H}_{4}\right)_{2} \mathrm{BOH}$; see the Supporting Information).

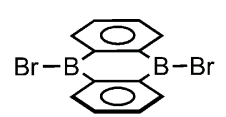

6
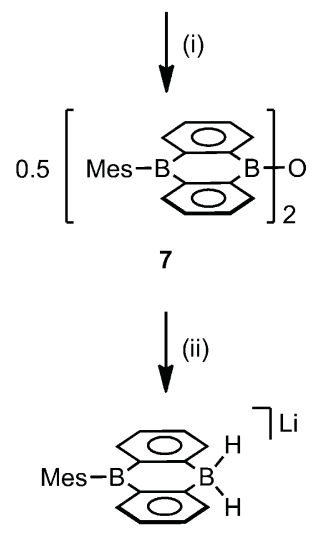

8

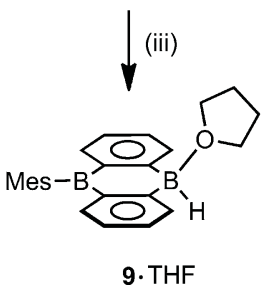

Scheme 3. Synthesis of compounds 7-9.THF. Reagents and conditions i) 1) $\mathrm{MesMgBr}$ (1 equiv), toluene, $-78^{\circ} \mathrm{C} \rightarrow$ room temperature; 2) $\mathrm{H}_{2} \mathrm{O}$ (excess), $\mathrm{CHCl}_{3}$, room temperature; ii) $\mathrm{LiAlH}_{4}$ (1 equiv), $\mathrm{Et}_{2} \mathrm{O} / \mathrm{THF}$, room temperature; iii) $\mathrm{Me}_{3} \mathrm{SiCl}$ (excess), $\mathrm{Et}_{2} \mathrm{O} / \mathrm{THF}$, room temperature.

The solid-state structure of 7 reveals the desired compound with peripheral mesityl substituents (Figure 2; Table 1). Compared with $\mathbf{2}$, subtle differences are observed for the central B-O-B linker $\left((\mathrm{B}-\mathrm{O})_{\mathrm{av}}=1.366(4) \AA\right.$ (7) vs. 1.341(7) $\AA$ (2); $\mathrm{B}-\mathrm{O}-\mathrm{B}=139.4(2)^{\circ}$ (7) vs. $\left.156.5(5)^{\circ}(\mathbf{2})\right)$. As

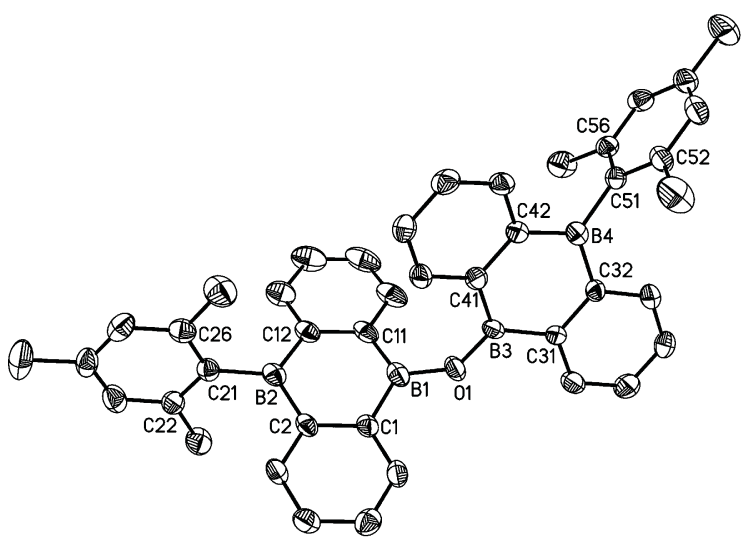

Figure 2. Molecular structure of $\mathbf{7}$ in the solid state; displacement ellipsoids at the $50 \%$ probability level, $\mathrm{H}$ atoms omitted for clarity. Selected bond lengths $[\AA]$, bond angle $\left[{ }^{\circ}\right]$, and dihedral angles $\left[^{\circ}\right]$ : B1-O1 1.371(4), B3-O1 1.361(3), B2-C21 1.568(4), B4-C51 1.571(4); B1-O1-B3 139.4(2); C1-B1-C11//C31-B3-C41 74.5(2), C2-B2-C12//C22-C21-C26 80.3(2), C32-B4-C42//C52-C51-C56 85.8(2). 
alluded to above, these variations are most likely due to crystal packing forces. Similar to $\mathbf{2}$, the two 9,10-dihydro9,10-diboraanthracene fragments of $\mathbf{7}$ are nearly orthogonal to each other $\left(\mathrm{C} 1-\mathrm{B} 1-\mathrm{C} 11 / / \mathrm{C} 31-\mathrm{B} 3-\mathrm{C} 41=74.5(2)^{\circ}\right)$. The dihedral angles between each 9,10-dihydro-9,10-diboraanthracene moiety and its attached mesityl substituent amount to $80.3(2)^{\circ}$ and $85.8(2)^{\circ}$. As a result, the vacant p-orbitals of B2 and B4 are efficiently shielded by methyl groups, which explains the stability of the triorganylborane units during the quenching process and chromatographic workup.

The ${ }^{11} \mathrm{~B}$ NMR spectrum of 7 contains two broad resonances at $\delta=43.9(B \mathrm{O})$ and $70.2 \mathrm{ppm}(B \mathrm{Mes})$ in the typical region ${ }^{[21]}$ of three-coordinate boron atoms. In the ${ }^{1} \mathrm{H}$ NMR spectrum, signals that can be assigned to the mesityl substituents appear at $\delta=2.16\left(o-\mathrm{CH}_{3}\right), 2.35\left(p-\mathrm{CH}_{3}\right)$, and $6.93 \mathrm{ppm}(\mathrm{MesH}-3,5)$. The general pattern of the phenylene resonances is largely the same as in $\mathbf{2}$.

Synthesis of $\operatorname{Mes} B\left(\mathrm{C}_{6} \mathrm{H}_{4}\right)_{2} B X(X=\mathrm{H}, \mathrm{Br})$ : For the further derivatization of $\mathbf{7}$, we first tested the approach involving $\mathrm{LiAlH}_{4}$ that was employed in the case of $\mathbf{3}$. Lithium dihydridoborate $\mathbf{8}$ (Scheme 3) readily formed upon addition of two equivalents of $\mathrm{LiAlH}_{4}$ in THF to a solution of $\mathbf{7}$ in $\mathrm{Et}_{2} \mathrm{O}$. In contrast to the analogous reaction of $\mathbf{3}$, in this case, we found no indication of any accompanying cleavage of $\mathrm{B}-\mathrm{C}$ bonds. Addition of excess $\mathrm{Me}_{3} \mathrm{SiCl}$ to a solution of $\mathbf{8}$ in $\mathrm{Et}_{2} \mathrm{O} / \mathrm{THF}$ led to the abstraction of one of the boron-bound hydride ions accompanied by formation of the THF adduct 9.THF (Scheme 3). Compound 9.THF smoothly hydroborates terminal alkynes $\mathrm{RC} \equiv \mathrm{CH}$ (stoichiometric ratio=1:1) even at room temperature with formation of the corresponding vinyl boranes (double hydroboration was never observed). However, a drawback of the $\mathrm{LiAlH}_{4}$ mediated route to 9.THF was that $\mathbf{8}, \mathbf{9} \cdot \mathrm{THF}$, and even the hydroboration products are difficult to purify from contaminating aluminum salts, especially from the highly soluble complex $\left[\mathrm{AlCl}_{3}(\mathrm{THF})_{2}\right]$. The preparation of analytically pure samples requires fractional crystallization, which is not only time consuming but also reduces the yields considerably. We therefore decided to look for an improved route to compounds of type 9. Thus synthesis details of $\mathbf{8}$ and 9.THF, a full NMR characterization and their X-ray crystal structure analyses are provided only as Supporting Information.

Because certain alkylaryl ethers are readily cleaved with $\mathrm{BBr}_{3},{ }^{[24]}$ we tested whether boronic acid anhydride 7 could also be transformed into a bromoborane upon treatment with $\mathrm{BBr}_{3}$. Indeed, by stirring a solution of 7 in $\mathrm{C}_{6} \mathrm{H}_{6}$ with 4 equiv of $\mathrm{BBr}_{3}$, clean and quantitative $\mathrm{O} / \mathrm{Br}$ exchange was observed to take place within $31 \mathrm{~h}$ at room temperature (Scheme 4; see the Supporting Information for a series of ${ }^{1} \mathrm{H}$ NMR spectra that show the progress of the reaction). We note in this context that the resulting bromoborane MesB$\left(\mathrm{C}_{6} \mathrm{H}_{4}\right)_{2} \mathrm{BBr}$ (10) had already been observed as the main product of the reaction between $\mathrm{BrB}\left(\mathrm{C}_{6} \mathrm{H}_{4}\right)_{2} \mathrm{BBr}(6)$ and $\mathrm{Mes} \mathrm{MgBr}$, but could not be isolated in pure form from the reaction mixture. Generation of the air- and moisture-stable

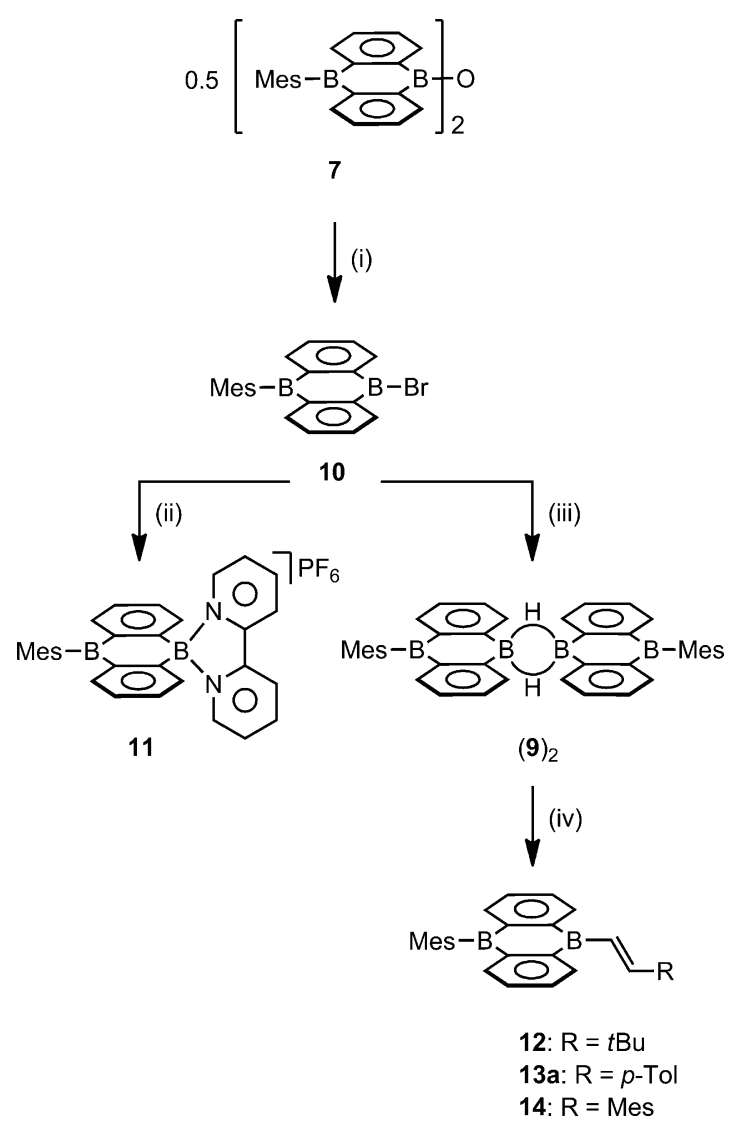

Scheme 4. Synthesis of compounds $(\mathbf{9})_{2}, \mathbf{1 0}-\mathbf{1 4}$. Reagents and conditions: i) $\mathrm{BBr}_{3}$ (2 equiv), $\mathrm{C}_{6} \mathrm{H}_{6}$, room temperature; ii) 1) 2,2'-bipy (1 equiv), $\mathrm{C}_{6} \mathrm{H}_{6} /$ toluene, room temperature; 2) $\mathrm{NH}_{4} \mathrm{PF}_{6}$ (excess), $\mathrm{MeOH} / \mathrm{H}_{2} \mathrm{O}$, room temperature; iii) $\mathrm{Et}_{3} \mathrm{SiH}$ (excess), room temperature; iv) $\mathrm{RC} \equiv \mathrm{CH}$ (1 equiv), $\mathrm{C}_{6} \mathrm{H}_{6}$, room temperature.

borinic acid anhydride 7 now enables convenient access to this important component.

Compound $\mathbf{1 0}$ was characterized by NMR spectroscopic and X-ray crystallographic analyses. The ${ }^{11} \mathrm{~B}$ NMR spectroscopic data of the compound $(\delta=65.0$ and $69.4 \mathrm{ppm})$ are very similar to those of 6 on the one hand $(\delta=63.8 \mathrm{ppm}$; see the Supporting Information) and $\mathrm{MesB}\left(\mathrm{C}_{6} \mathrm{H}_{4}\right)_{2} \mathrm{BMes}$ on the other $\left(\delta=66.0 \mathrm{ppm}^{[18]}\right)$. All ${ }^{1} \mathrm{H}$ and ${ }^{13} \mathrm{C}$ NMR signals of $\mathbf{1 0}$ appear in the expected chemical shift regions and therefore are not discussed further. The solid-state structure of $\mathbf{1 0}$ (Figure 3, Table 1) shows essentially the same bond lengths and angles about B1 (B1-Br1=1.949(6) $\AA$; C1-B1-C11= $\left.123.8(5)^{\circ}\right)$ and $\mathrm{B} 2 \quad(\mathrm{~B} 2-\mathrm{C} 21=1.564(7) \AA$; $\quad \mathrm{C} 2-\mathrm{B} 2-\mathrm{C} 12=$ $\left.119.1(5)^{\circ}\right)$ as those of 6 (see the Supporting Information) and $\mathrm{MesB}\left(\mathrm{C}_{6} \mathrm{H}_{4}\right)_{2} \mathrm{BMes},{ }^{[18]}$ respectively.

Bromoborane $\mathbf{1 0}$ cleanly undergoes substitution reactions with reagents as different as 2,2'-bipyridyl and $\mathrm{Et}_{3} \mathrm{SiH}$ (Scheme 4). In the first case, we obtained a water-stable $2,2^{\prime}$-bipyridylboronium bromide salt, which was transformed into the hexafluorophosphate salt $\mathbf{1 1}$ by metathesis with $\mathrm{NH}_{4} \mathrm{PF}_{6}$. In the second case, crystals of the hydridoborane $(\mathbf{9})_{2}$ were grown from a solution of $\mathbf{1 0}$ in $\mathrm{Et}_{3} \mathrm{SiH}$. 


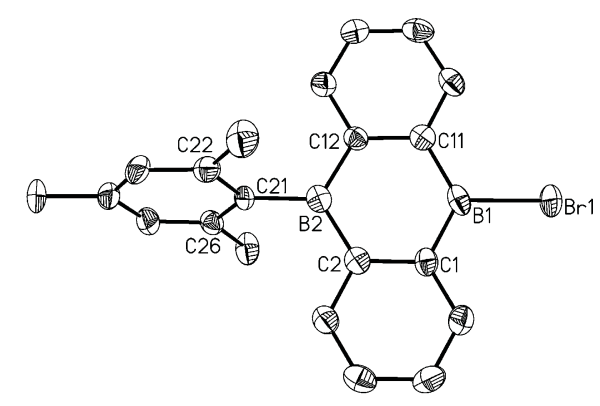

Figure 3. Molecular structure of $\mathbf{1 0}$ in the solid state; displacement ellipsoids at the $50 \%$ probability level, $\mathrm{H}$ atoms omitted for clarity. Selected bond lengths $[\AA]$, bond angles $\left[{ }^{\circ}\right]$, and dihedral angle $\left[^{\circ}\right]$ : $\mathrm{B} 1-\mathrm{Br} 1$ 1.949(6), B1-C1 1.534(8), B1-C11 1.561(8), B2-C2 1.551(7), B2-C12 1.567(8), B2-C21 1.564(7); C1-B1-C11 123.8(5), C2-B2-C12 119.1(5); C2$\mathrm{B} 2-\mathrm{C} 12 / / \mathrm{C} 22-\mathrm{C} 21-\mathrm{C} 26$ 81.0(4).

The ${ }^{11} \mathrm{~B}$ NMR spectrum of $\mathbf{1 1}$ shows signals at $\delta=69.5$ and $5.5 \mathrm{ppm}$, testifying to the presence of three- and four-coordinate boron atoms, respectively. ${ }^{[21]}$ In the ${ }^{1} \mathrm{H}$ NMR spectrum, the integral ratios of the mesityl, 9,10-dihydro-9,10-diboraanthracene, and 2,2'-bipyridyl resonances indicate a 1:1:1 ratio of the three fragments in the molecule. Most of the ${ }^{1} \mathrm{H}$ NMR signals of the coordinating 2,2'-bipyridyl ligand appear at lower field than those of the free base. The same is true for most of the ${ }^{13} \mathrm{C} \mathrm{NMR}$ signals, a characteristic exception $^{[25]}$ being the resonance of bipyC-2,2', which experiences an upfield shift of $9.3 \mathrm{ppm}$ in 11. The X-ray crystal structure analysis of $\mathbf{1 1}$ is in full accord with the structure established by NMR spectroscopy (see the Supporting Information).

Compound 9 forms a centrosymmetric B-H-B bridged dimer $(\mathbf{9})_{2}$ in the solid state (Figure 4; Table 2), which is reminiscent of the coordination polymer $(\mathbf{B})_{n} \cdot{ }^{[13]}$ The 9,10-dihydro-9,10-diboraanthracene cores of the monomeric moieties in $(\mathbf{9})_{2}$ deviate significantly from planarity, with a dihedral angle of $146.7(1)^{\circ}$ between the two phenylene rings $\operatorname{Ar}(\mathrm{C} 1) / / \operatorname{Ar}(\mathrm{C} 11)$. An even stronger folding has been observed in $(\mathbf{B})_{n}\left(133.8^{\circ}\right)$ and is accompanied by an intermono-

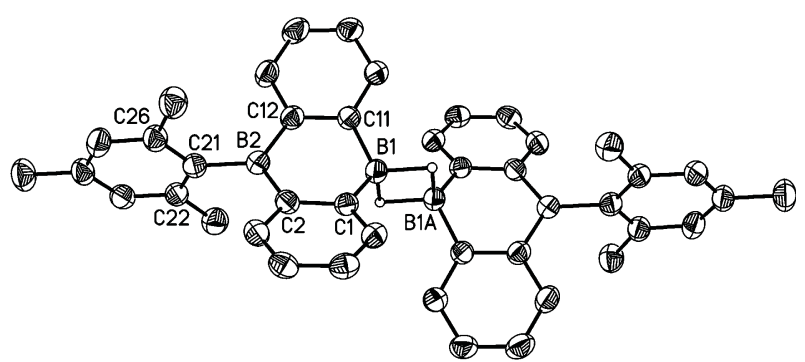

Figure 4. Molecular structure of $(9)_{2}$ in the solid state; displacement ellipsoids at the $50 \%$ probability level, $\mathrm{H}$ atoms (except on boron) omitted for clarity. Selected bond lengths $[\AA]$, atom $\cdots$ atom distance $[\AA]$, bond angles $\left[^{\circ}\right]$, torsion angles $\left[{ }^{\circ}\right]$, and dihedral angles $\left[^{\circ}\right]$ : B1-C1 1.574(3), B1-C11 1.575(3), B2-C2 1.560(3), B2-C12 1.562(3), B2-C21 1.582(3), B1B1A 1.850(5); C1-B1-C11 117.3(2), C2-B2-C12 118.2(2); B1-C1-C2B2 -6.6(3), B1-C11-C12-B2 12.2(3); C2-B2-C12//C22-C21-C26 85.7(2), $\operatorname{Ar}(\mathrm{C} 1) / / \operatorname{Ar}(\mathrm{C} 11)$ 146.7(1). Symmetry transformation used to generate equivalent atoms: $\mathrm{A}:-x,-y+1,-z+1$.
Table 2. Crystallographic data for $(\mathbf{9})_{2}$ and $\mathbf{1 4}$.

\begin{tabular}{|c|c|c|}
\hline & $(\mathbf{9})_{2}$ & 14 \\
\hline formula & $\mathrm{C}_{42} \mathrm{H}_{40} \mathrm{~B}_{4}$ & $\mathrm{C}_{32} \mathrm{H}_{32} \mathrm{~B}_{2}$ \\
\hline$M_{\mathrm{r}}$ & 587.98 & 438.20 \\
\hline color, shape & yellow, block & colorless, plate \\
\hline$T[\mathrm{~K}]$ & $173(2)$ & $173(2)$ \\
\hline radiation, $\lambda[\AA]$ & $\mathrm{Mo}_{\mathrm{K} \alpha}, 0.71073$ & $\mathrm{Mo}_{\mathrm{K} \alpha}, 0.71073$ \\
\hline crystal system & monoclinic & monoclinic \\
\hline space group & $P 2_{1} / n$ & $P 2_{1} / n$ \\
\hline$a[\AA]$ & $7.2197(7)$ & $16.133(4)$ \\
\hline$b[\AA]$ & $13.7689(13)$ & $14.936(3)$ \\
\hline$c[\AA]$ & $16.990(2)$ & $22.143(6)$ \\
\hline$\alpha\left[^{\circ}\right]$ & 90 & 90 \\
\hline$\beta\left[^{\circ}\right]$ & $91.156(9)$ & $107.42(2)$ \\
\hline$\gamma\left[^{\circ}\right]$ & 90 & 90 \\
\hline$V\left[\AA^{3}\right]$ & $1688.6(3)$ & $5091(2)$ \\
\hline$Z$ & 2 & 8 \\
\hline$\rho_{\text {calcd }}\left[\mathrm{g} \mathrm{cm}^{-3}\right]$ & 1.156 & 1.143 \\
\hline $\mathrm{F}(000)$ & 624 & 1872 \\
\hline$\mu\left[\mathrm{mm}^{-1}\right]$ & 0.063 & 0.063 \\
\hline crystal size $[\mathrm{mm}]$ & $0.37 \times 0.35 \times 0.35$ & $0.28 \times 0.25 \times 0.12$ \\
\hline reflections collected & 13587 & 31262 \\
\hline independent reflections $\left(R_{\text {int }}\right)$ & $2977(0.1042)$ & $8953(0.3476)$ \\
\hline data/restraints/parameters & $2977 / 0 / 215$ & $8953 / 15 / 624$ \\
\hline GOF on $F^{2}$ & 0.926 & 0.719 \\
\hline$R_{1}, w R_{2}[I>2 \sigma(I)]$ & $0.0532,0.1209$ & $0.0752,0.1029$ \\
\hline$R_{1}, w R_{2}$ (all data) & $0.0947,0.1371$ & $0.3396,0.1964$ \\
\hline largest diff peak and hole $\left[\mathrm{e} \AA^{-3}\right]$ & $0.279,-0.187$ & $0.216,-0.176$ \\
\hline
\end{tabular}

mer $\mathrm{B} \cdots \mathrm{B}$ distance of $1.818(12) \AA$ (mean value) as opposed to a longer distance of $1.850(5) \AA$ in $(9)_{2}$. We note that the $\mathrm{B} \cdots \mathrm{B}$ distance in $(9)_{2}$ is also longer than that of $\left(\left(\mathrm{C}_{6} \mathrm{~F}_{5}\right)_{2} \mathrm{BH}\right)_{2}$ $\left(1.799(7) \AA^{[26]}\right)$, but is comparable to that of the sterically congested molecule $\left(\mathrm{Mes}_{2} \mathrm{BH}\right)_{2}\left(1.851(3) \AA^{[27]}\right)$. The experimentally determined structure of $(\mathbf{9})_{2}$ is in good agreement with the theoretically predicted structure of the parent dimer $\mathrm{HB}\left(\mathrm{C}_{6} \mathrm{H}_{4}\right)_{2} \mathrm{~B}(\mu-\mathrm{H})_{2} \mathrm{~B}\left(\mathrm{C}_{6} \mathrm{H}_{4}\right)_{2} \mathrm{BH}\left((\mathbf{B})_{2}\right){ }^{[13]}$ The following observations can be made: 1$)$ The simultaneous presence of three- and four-coordinate boron centers results in a puckering of the central six-membered ring [absolute values of the torsion angles B-C-C-B $=6.6(3)^{\circ}, 12.2(3)^{\circ}\left((9)_{2}\right) ; 10.4^{\circ}$ $\left.\left.\left((\mathbf{B})_{2}\right)\right] . \quad 2\right)$ The dihedral angle $\operatorname{Ar}(\mathrm{C} 1) / / \operatorname{Ar}(\mathrm{C} 11)$ equals $146.7(1)^{\circ}$ in $(\mathbf{9})_{2}$ vs. $151^{\circ}$ in $(\mathbf{B})_{2}$. 3) The intermonomer B $\cdots \mathrm{B}$ distance is $1.850(5) \AA$ in $(\mathbf{9})_{2}$ and $1.83 \AA$ in $(\mathbf{B})_{2}$.

DFT calculations indicate that the dimerization of $\mathbf{B}$ is essentially a thermoneutral process $\left(\Delta G^{298}=0.3 \mathrm{kcal} \mathrm{mol}^{-1}\right)$ under gas-phase conditions. ${ }^{[13]}$ In $\mathrm{C}_{6} \mathrm{D}_{6}$ solution, the ${ }^{11} \mathrm{~B}$ NMR spectrum of 9 is characterized by only one broad resonance at $\delta=71.0 \mathrm{ppm}$, which lies in the typical shift range of three-coordinate boron centers and can be explained in two ways: 1) the $B H$ resonance is broadened beyond detection (for example, as a result of a monomerdimer equilibrium), or 2) the $B \mathrm{H}^{[27]}$ and $B$ Mes signals are overlapping, which would necessarily mean that $\mathbf{9}$ exists as a monomer under the measurement conditions. The ${ }^{1} \mathrm{H}$ and ${ }^{13} \mathrm{C}$ NMR spectra in $\mathrm{C}_{6} \mathrm{D}_{6}$ both reveal one set of signals, all of which are narrow and well-resolved and therefore give no indication of an ongoing slow dynamic process. Remarkably, the ${ }^{13} \mathrm{C}$ nuclei of the 9,10-dihydro-9,10-diboraanthracene core are comparatively deshielded and possess chemical 
shift values $(\delta=133.7,134.2,139.0$, and $142.0 \mathrm{ppm})$ closer to those of $\mathbf{1 2}$ (see below; $\delta=132.7,133.1,137.1$, and $139.4 \mathrm{ppm})$ than to those of 9.THF $(\delta=126.9,132.2,135.5$, and $138.6 \mathrm{ppm})$, or $\mathbf{8}(\delta=121.7,128.8,135.0$, and $138.1 \mathrm{ppm})$. The IR spectrum of 9 in $\mathrm{C}_{6} \mathrm{H}_{6}$ shows an absorption at $2481 \mathrm{~cm}^{-1}$, which is typical of terminal $\mathrm{B}-\mathrm{H}$ stretching bands ${ }^{[28]}$ (this absorption is absent in the IR spectrum of solid $(9)_{2}$ ). In summary, based on our spectroscopic results and on the DFT calculations mentioned above, we suggest that 9 mainly exists as monomeric species in aromatic solvents. This conclusion is also in accord with the evidence we have gathered for an unusually weak $\mathrm{B}-\mathrm{O}$ bond in 9.THF (see the Supporting Information). In $\left[\mathrm{D}_{8}\right] \mathrm{THF}$, the NMR spectra of $(\mathbf{9})_{2}$ are identical to those of compound 9.THF.

Upon irradiation with UV light $(\lambda=366 \mathrm{~nm})$ at room temperature, compound 9 shows a bright blue-green fluorescence in $\mathrm{C}_{6} \mathrm{H}_{6}$ or THF solution. When the THF solution is cooled to liquid nitrogen temperature, the emission of the sample becomes more intense; when the UV light was switched off, an intense delayed luminescence remained visible for more than $15 \mathrm{~s}$ (the optical properties of 9 and of selected derivatives are the subject of ongoing investigations).

Hydroboration reactions of $\mathrm{Mes} B\left(\mathrm{C}_{6} \mathrm{H}_{4}\right)_{2} \mathrm{BH}$ : Compound 9.THF as well as donor-free 9 have been employed in our studies on the hydroboration of terminal alkynes. Both reagents undergo quantitative conversion into the corresponding vinyl boranes (NMR spectroscopic monitoring of the reaction).

In a first exploratory NMR experiment, the reaction of 9.THF with 1.2 equiv of $t \mathrm{BuC} \equiv \mathrm{CH}$ gave the vinyl borane 12 (Scheme 4) with excellent regioselectivity. Two doublets were observed at $\delta=6.70$ and $7.03 \mathrm{ppm}$ in the ${ }^{1} \mathrm{H} \mathrm{NMR}$ spectrum with a ${ }^{3} J(\mathrm{H}, \mathrm{H})$ coupling constant of $18.1 \mathrm{~Hz}$, which is indicative of an E-olefin (see the Supporting Information).

The regioselectivity was drastically reduced when $p$-TolC $\equiv \mathrm{CH}$ was used instead of $t \mathrm{BuC} \equiv \mathrm{CH} \quad(p-\mathrm{Tol}=$ paratolyl), because the desired addition product 13a (Scheme 4) was obtained together with its isomer $\operatorname{MesB}\left(\mathrm{C}_{6} \mathrm{H}_{4}\right)_{2} \mathrm{BC}(p$ Tol $)=\mathrm{CH}_{2}(\mathbf{1 3 b})$ in a 2:1 ratio. Similar to 12, the olefinic fragment of 13a gives rise to two doublet proton resonances $(\delta=7.47$ and $7.82 \mathrm{ppm})$ with a ${ }^{3} J(\mathrm{H}, \mathrm{H})$ coupling constant of $18.2 \mathrm{~Hz}$; in contrast, the ${ }^{1} \mathrm{H}$ NMR spectrum of $\mathbf{1 3 b}$ is characterized by two doublets $(\delta=5.30$ and $6.27 \mathrm{ppm})$ with a ${ }^{2} J$ $(\mathrm{H}, \mathrm{H})$ coupling constant of only $1.8 \mathrm{~Hz}$ (see the Supporting Information).

Given that one goal of the work presented herein was the synthesis of well-defined, fully conjugated, boron-doped $\pi$ electron systems, any regioselectivity problem associated with the hydroboration of (aryl)alkynes was a major issue that needed to be resolved. Switching from $p$-TolC $\equiv \mathrm{CH}$ to $\mathrm{Mes} C \equiv \mathrm{CH},{ }^{[29]}$ we tested whether a moderate increase in the steric demand of the aryl group led to the selective formation of species of type 13a. Indeed, the reactions between 9. THF or 9 and MesC $\equiv \mathrm{CH}$ furnished isomer 14 exclusively (Scheme 4; $\mathrm{BC}(H)=\mathrm{C}(H): \delta\left({ }^{1} \mathrm{H}\right)=7.34,7.52 \mathrm{ppm}, 2 \times \mathrm{d}$, $\left.{ }^{3} J(\mathrm{H}, \mathrm{H})=18.8 \mathrm{~Hz}\right)$. These syntheses were also conducted on a preparative scale with isolation and full characterization of the product. Crude 14, prepared from 9.THF without previous isolation of the intermediate $\mathbf{8}$ (in the form of $\mathbf{8} \cdot(\mathrm{THF})_{3}$, see the Supporting Information), tended to be contaminated with the aluminum complex $\left[\mathrm{AlCl}_{3}(\mathrm{THF})_{2}\right]$. Compound 14 and $\left[\mathrm{AlCl}_{3}(\mathrm{THF})_{2}\right]$ could be separated from each other by fractional crystallization from hexane at $4{ }^{\circ} \mathrm{C}\left(\left[\mathrm{AlCl}_{3^{-}}\right.\right.$ $\left.\left.(\mathrm{THF})_{2}\right]\right)$ and $-30^{\circ} \mathrm{C}(\mathbf{1 4})$. To obtain analytically pure 14 from 9 and $\mathrm{MesC} \equiv \mathrm{CH}$, it is sufficient to remove all volatiles from the reaction mixture under vacuum and to reprecipitate the product from hexane at $-78^{\circ} \mathrm{C}$.

The targeted hydrolysis of $\mathbf{1 4}$ with traces of added $\mathrm{H}_{2} \mathrm{O}$ gave 7 and $\mathrm{H}_{2} \mathrm{C}=\mathrm{C}(\mathrm{H})$ Mes in a clean and quantitative reaction, thereby identifying the $\mathrm{B}-\mathrm{C}$ (vinyl) bond as the weakest link in the molecule.

Compound 14 crystallizes with two crystallographically independent molecules, $\mathbf{1 4}_{\mathbf{A}}$ and $\mathbf{1 4} \mathbf{B}$, in the asymmetric unit. The X-ray crystal structure analysis shows the desired antiMarkownikow isomer and the expected $E$-configuration of the $\mathrm{C}=\mathrm{C}$ double bond (Figure 5). Given the poor quality of the data set (Table 2), we refrain from a detailed description of bond lengths and angles.

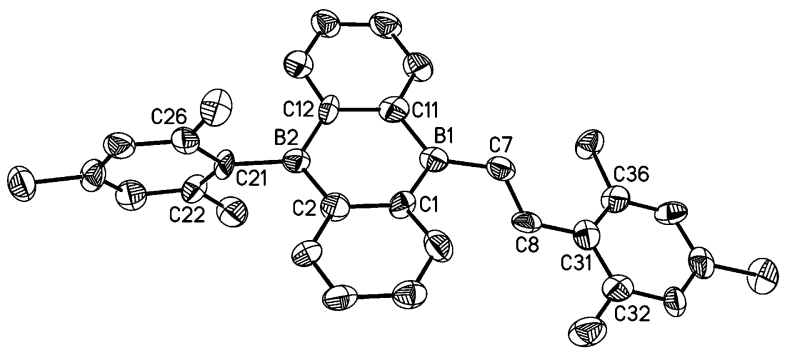

Figure 5. Molecular structure of $\mathbf{1 4}_{\mathbf{A}}$ in the solid state; displacement ellipsoids at the $50 \%$ probability level, $\mathrm{H}$ atoms omitted for clarity. Selected bond lengths $[\AA]$, bond angles $\left[{ }^{\circ}\right]$, and dihedral angles $\left[^{\circ}\right]$ : B1-C1 $1.568(13), \mathrm{B} 1-\mathrm{C} 7$ 1.548(11), B1-C11 1.580(14), B2-C2 1.581(14), B2$\mathrm{C} 12$ 1.562(13), B2-C21 1.551(13), C7-C8 1.329(9); C7-B1-C1 120.5(9), C7-B1-C11 121.6(8), C1-B1-C11 117.5(8), C2-B2-C12 119.2(8), B1-C7-C8 124.8(8), C7-C8-C31 128.8(7); C1-B1-C11//B1-C7-C8 41(1), C2-B2-C12// C22-C21-C26 77.8(7).

Comparison of the electronic spectra of 14 and $\mathrm{Mes}_{2} B C(H)=$ $C(H) M e s:$ To compare the optical properties of the [MesB$\left(\mathrm{C}_{6} \mathrm{H}_{4}\right)_{2} \mathrm{~B}$ ] chromophore with those of the commonly used $\left[\mathrm{Mes}_{2} \mathrm{~B}\right]$ group, we prepared the compound $\mathrm{Mes}_{2} \mathrm{BC}(\mathrm{H})=$ $\mathrm{C}(\mathrm{H}) \mathrm{Mes}$ (see the Supporting Information for synthetic details and NMR data), which is an analogue of 14. The absorption and emission wavelengths of both compounds are compiled in Table 3.

Table 3. Electronic spectral data of $\mathbf{1 4}$ and $\mathrm{Mes}_{2} \mathrm{BC}(\mathrm{H})=\mathrm{C}(\mathrm{H}) \mathrm{Mes}$ in toluene.

\begin{tabular}{lll}
\hline Compound & $\lambda_{\max }(\mathrm{abs})[\mathrm{nm}]$ & $\lambda_{\max }(\mathrm{em})[\mathrm{nm}]$ \\
\hline $\mathbf{1 4}$ & 350 & $470\left(\lambda_{\mathrm{ex}}=350\right)$ \\
$\mathrm{Mes}_{2} \mathrm{BC}(\mathrm{H})=\mathrm{C}(\mathrm{H}) \mathrm{Mes}$ & 333 & $396\left(\lambda_{\mathrm{ex}}=335\right)$ \\
\hline
\end{tabular}


In toluene solution, $\mathrm{Mes}_{2} \mathrm{BC}(\mathrm{H})=\mathrm{C}(\mathrm{H})$ Mes shows its longest wavelength absorption at $\lambda_{\max }(\mathrm{abs})=333 \mathrm{~nm}$; the emission maximum of the compound lies at $\lambda_{\max }(\mathrm{em})=396 \mathrm{~nm}$ (excitation wavelength: $\lambda_{\mathrm{ex}}=335 \mathrm{~nm}$ ). Both $\lambda_{\max }$ values compare perfectly well with those of the closely related compound $\mathrm{Mes}_{2} \mathrm{BC}(\mathrm{H})=\mathrm{C}(\mathrm{H}) \mathrm{Ph} \quad\left(\lambda_{\max }(\mathrm{abs})=332 \mathrm{~nm} / \lambda_{\max }(\mathrm{em})=\right.$ $398 \mathrm{~nm}$ in cyclohexane). ${ }^{[30]}$ Replacement of $\left[\mathrm{Mes}_{2} \mathrm{~B}\right]$ by $\left[\mathrm{MesB}\left(\mathrm{C}_{6} \mathrm{H}_{4}\right)_{2} \mathrm{~B}\right]$ had only a moderate effect on the absorption band, which, in the latter case, appears at $\lambda_{\max }(\mathrm{abs})=$ $350 \mathrm{~nm}$ (14). The emission band, however, undergoes a bathochromic shift of $\Delta \lambda=74 \mathrm{~nm}$ and is found at $\lambda_{\max }(\mathrm{em})=$ $470 \mathrm{~nm}(\mathbf{1 4})$. These qualitative trends are in line with expectations, because more extended and conformationally constrained dyes are known to absorb and fluoresce more intensely at longer wavelengths relative to smaller and/or unconstrained dyes. ${ }^{[31]}$

\section{Conclusion}

Two convenient, high-yield protocols for the synthesis of unsymmetrically substituted 9,10-dihydro-9,10-diboraanthracenes have been developed: The first starts from a thioether adduct of the parent borane (i.e., $\left(\mathrm{Me}_{2} \mathrm{~S}\right) \mathrm{HB}\left(\mathrm{C}_{6} \mathrm{H}_{4}\right)_{2} \mathrm{BH}$ $\left.\left(\mathrm{SMe}_{2}\right) ; \mathbf{1}\right)$, the second from $\mathrm{BrB}\left(\mathrm{C}_{6} \mathrm{H}_{4}\right)_{2} \mathrm{BBr}(\mathbf{6})$. In the case of $\mathbf{1}$, it is possible to break the symmetry of the molecular framework by targeted hydrolysis, which gives the borinic acid anhydride $\left(\left(\mathrm{Me}_{2} \mathrm{~S}\right) \mathrm{HB}\left(\mathrm{C}_{6} \mathrm{H}_{4}\right)_{2} \mathrm{~B}\right)_{2} \mathrm{O}(2)$ in almost $50 \%$ yield as a crystalline solid. In the case of $\mathbf{6}$, the reaction with 1 equiv of $\mathrm{MesMgBr}$ under high dilution leads to the preferential formation of $\mathrm{MesB}\left(\mathrm{C}_{6} \mathrm{H}_{4}\right)_{2} \mathrm{BBr}$, which is subsequently transformed into the air- and moisture-stable borinic acid anhydride $\left(\mathrm{MesB}\left(\mathrm{C}_{6} \mathrm{H}_{4}\right)_{2} \mathrm{~B}\right)_{2} \mathrm{O}(\mathbf{7} ; 76 \%$ yield $)$ to facilitate purification.

Compound 2 can be used directly for further derivatization through hydroboration. Compound 7 reacts cleanly with $\mathrm{BBr}_{3}$ to regenerate the monotopic bromoborane MesB$\left(\mathrm{C}_{6} \mathrm{H}_{4}\right)_{2} \mathrm{BBr}(\mathbf{1 0})$, which, in turn, reacts with $\mathrm{Et}_{3} \mathrm{SiH}$ to furnish the borane MesB $\left(\mathrm{C}_{6} \mathrm{H}_{4}\right)_{2} \mathrm{BH}(\mathbf{9})$. Having both 9 and $\mathbf{1 0}$ available, it is now possible to conveniently attach the $\left[\mathrm{MesB}\left(\mathrm{C}_{6} \mathrm{H}_{4}\right)_{2} \mathrm{~B}\right]$ fragment to conjugated $\pi$-electron systems either through hydroboration or nucleophilic substitution protocols, respectively.

Compound 9 is also accessible as its THF-adduct 9.THF by treatment of 7 with $\mathrm{LiAlH}_{4}$ and then with $\mathrm{Me}_{3} \mathrm{SiCl}$ in $\mathrm{Et}_{2} \mathrm{O} / \mathrm{THF}$. Compared with the sequence $\mathbf{7} \rightarrow \mathbf{1 0} \rightarrow \mathbf{9}$, this alternative route has the disadvantage that it usually takes some effort to purify 9.THF (or its hydroboration products) from residual aluminum complexes.

The electronic absorption and emission spectra of the vinyl borane $\mathrm{MesB}\left(\mathrm{C}_{6} \mathrm{H}_{4}\right)_{2} \mathrm{BC}(\mathrm{H})=\mathrm{C}(\mathrm{H})$ Mes reveal bathochromic shifts of $\Delta \lambda(\mathrm{abs})=17 \mathrm{~nm}$ and $\Delta \lambda(\mathrm{em})=74 \mathrm{~nm}$, compared with $\mathrm{Mes}_{2} \mathrm{BC}(\mathrm{H})=\mathrm{C}(\mathrm{H}) \mathrm{Mes}$, which bears the more common $\left[\mathrm{Mes}_{2} \mathrm{~B}\right]$ chromophore. This observation strongly suggests that the optoelectronic properties resulting from the more extended 9,10-dihydro-9,10-diboraanthracene $\pi$ system increase the value of the material. We are therefore planning to prepare yet larger but still well-defined borondoped $\pi$ materials, for example, by replacing the monoalkyne $\mathrm{Mes} C \equiv \mathrm{CH}$ with the aromatic dialkyne $\mathrm{HC} \equiv \mathrm{C}(p$ $\left.\mathrm{C}_{6} \mathrm{Me}_{4}\right) \mathrm{C} \equiv \mathrm{CH}$.

\section{Experimental Section}

Unless otherwise specified, all reactions were carried out under dry nitrogen or argon using Schlenk or glove box techniques. Hexane, toluene, $\mathrm{C}_{6} \mathrm{H}_{6}, \mathrm{C}_{6} \mathrm{D}_{6}, \mathrm{Et}_{2} \mathrm{O}$, THF, and $\left[\mathrm{D}_{8}\right] \mathrm{THF}$ were dried over $\mathrm{Na}$ /benzophenone. $\mathrm{Me}_{2} \mathrm{~S}$ was stirred over $\mathrm{LiAlH}_{4}$ for $8 \mathrm{~h}$ at room temperature and distilled prior use. $\mathrm{Me}_{3} \mathrm{SiCl}$ was stored over $\mathrm{CaH}_{2}$ and distilled prior to use. $t \mathrm{BuC} \equiv \mathrm{CH}$ and $\mathrm{Et}_{3} \mathrm{SiH}$ were distilled from molecular sieves $(3 \AA$ ). NMR spectra were recorded with Bruker AM 250, DPX 250, Avance 300, or Avance 400 spectrometers at room temperature, if not otherwise specified. Chemical shifts are referenced to (residual) solvent signals $\left({ }^{1} \mathrm{H} /{ }^{13} \mathrm{C}\left\{{ }^{1} \mathrm{H}\right\} ; \quad \mathrm{C}_{6} \mathrm{D}_{6}: \quad \delta=7.15 / 128.0 \mathrm{ppm} ; \quad\left[\mathrm{D}_{8}\right] \mathrm{THF}: \quad \delta=3.58 / 67.4 \mathrm{ppm}\right.$; $\left.\mathrm{CD}_{3} \mathrm{CN}: \delta=1.94 / 118.2 \mathrm{ppm}\right)$ or external $\mathrm{BF}_{3} \cdot \mathrm{Et}_{2} \mathrm{O}\left({ }^{11} \mathrm{~B},{ }^{11} \mathrm{~B}\left\{{ }^{1} \mathrm{H}\right\}\right)$. Abbreviations: $\mathrm{s}=$ singlet, $\mathrm{d}=$ doublet, $\mathrm{t}=$ triplet, app. $\mathrm{t}=$ apparent triplet, $\mathrm{m}=$ multiplet, br $=$ broad, n.o. $=$ signal not observed. UV/Vis absorption and emission spectra were recorded with a Varian Cary 50 Scan UV/Vis spectrophotometer or a Perkin-Elmer LS 50B fluorescence spectrometer, respectively. Combustion analyses were performed by the Microanalytical Laboratory of the University of Frankfurt and by the Microanalytical Laboratory Pascher. Compounds 1, ${ }^{[14]}$ 6, ${ }^{[22]} \mathrm{HOB}\left(\mathrm{C}_{6} \mathrm{H}_{4}\right)_{2} \mathrm{BOH},{ }^{[32]}$ 1,2$\mathrm{C}_{6} \mathrm{H}_{4}\left(\mathrm{SiMe}_{3}\right)_{2},{ }^{[12]} \mathrm{MesMgBr},{ }^{[23]}\left(\mathrm{Mes}_{2} \mathrm{BH}\right)_{2},{ }^{[33]}$ and $\mathrm{MesC} \equiv \mathrm{CH}^{[29]}$ were synthesized according to literature procedures.

Synthesis of 2: A calibrated solution of $\mathrm{H}_{2} \mathrm{O}$ in THF $(6.1 \mathrm{M}, 14.8 \mu \mathrm{L}$, $0.090 \mathrm{mmol}$ ) was added at room temperature by using an Eppendorf pipette to a stirred solution of $\mathbf{1}(0.050 \mathrm{~g}, 0.17 \mathrm{mmol})$ in anhydrous $\mathrm{Me}_{2} \mathrm{~S}$ (4 mL). After gas evolution $\left(\mathrm{H}_{2}\right)$ had ceased $(15 \mathrm{~min})$, the colorless clear solution was stored at $-80^{\circ} \mathrm{C}$ for 2 days. A colorless precipitate formed that was identified as unreacted $1(0.010 \mathrm{~g}, 20 \%)$. The clear supernatant was decanted in the cold and stored at $-80^{\circ} \mathrm{C}$ for another 4 days to obtain a colorless precipitate. The mother liquor was removed in the cold by using a syringe and discarded. The remaining solid was dried under

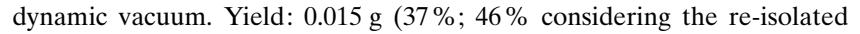
starting material). X-ray quality crystals of 2 were obtained through gasphase diffusion of pentane into a $\mathrm{Me}_{2} \mathrm{~S}$ solution of $\mathbf{2}$ at room temperature. ${ }^{1} \mathrm{H}$ NMR $\left(300.0 \mathrm{MHz}, \mathrm{C}_{6} \mathrm{D}_{6}\right): \delta=1.29\left(\mathrm{~s}, 12 \mathrm{H} ; \mathrm{SCH}_{3}\right), 4.23\left(h_{1 / 2}=\right.$ $100 \mathrm{~Hz}, 2 \mathrm{H} ; \mathrm{BH}), 7.19$ (app. td, ${ }^{3} J(\mathrm{H}, \mathrm{H})=7.4 \mathrm{~Hz},{ }^{4} J(\mathrm{H}, \mathrm{H})=1.2 \mathrm{~Hz}, 4 \mathrm{H}$; $\mathrm{H}-2,7$ or H-3,6), 7.43 (app. td, ${ }^{3} J(\mathrm{H}, \mathrm{H})=7.4 \mathrm{~Hz},{ }^{4} J(\mathrm{H}, \mathrm{H})=1.3 \mathrm{~Hz}, 4 \mathrm{H}$; H$2,7$ or $\mathrm{H}-3,6), 7.87\left(\mathrm{~d},{ }^{3} J(\mathrm{H}, \mathrm{H})=7.4 \mathrm{~Hz}, 4 \mathrm{H}\right.$; H-1,8 or $\left.\mathrm{H}-4,5\right), 8.17 \mathrm{ppm}$ $\left(\mathrm{d},{ }^{3} J(\mathrm{H}, \mathrm{H})=7.4 \mathrm{~Hz}, 4 \mathrm{H} ; \mathrm{H}-1,8\right.$ or $\left.\mathrm{H}-4,5\right) ;{ }^{11} \mathrm{~B} \mathrm{NMR}\left(96.3 \mathrm{MHz}, \mathrm{C}_{6} \mathrm{D}_{6}\right)$ : $\delta=-3.0\left(h_{1 / 2}=500 \mathrm{~Hz} ; \mathrm{BH}\right), 43.2 \mathrm{ppm}\left(h_{1 / 2}=1200 \mathrm{~Hz} ; \mathrm{BO}\right) ;{ }^{13} \mathrm{C}\left\{{ }^{1} \mathrm{H}\right\} \mathrm{NMR}$ $\left(62.9 \mathrm{MHz}, \mathrm{C}_{6} \mathrm{D}_{6}\right): \delta=18.2\left(\mathrm{SCH}_{3}\right), 126.9(\mathrm{C}-2,7$ or $\mathrm{C}-3,6), 130.6(\mathrm{C}-2,7$ or C-3,6), 133.6 (C-1,8 or C-4,5), 136.3 ppm (C-1,8 or C-4,5), n.o. (BC).

Synthesis of 7: A calibrated solution $(0.77 \mathrm{M})$ of the Grignard reagent $\mathrm{MesMgBr}$ was prepared in THF. An aliquot $(3.4 \mathrm{~mL}, 2.6 \mathrm{mmol})$ was transferred into a Schlenk vessel, all volatiles were removed under reduced pressure, the resulting brownish oil was dissolved in toluene $(15 \mathrm{~mL})$, and the solution was added dropwise with stirring at $-78^{\circ} \mathrm{C}$ to a turbid solution of $6(875 \mathrm{mg}, 2.62 \mathrm{mmol})$ in toluene $(100 \mathrm{~mL})$. The reaction mixture was allowed to warm to room temperature overnight, whereupon a colorless precipitate formed. After filtration, all volatiles were removed from the filtrate in vacuo to yield a yellow solid. Deionized $\mathrm{H}_{2} \mathrm{O}(20 \mathrm{~mL})$ and $\mathrm{CHCl}_{3}(50 \mathrm{~mL})$ were added, the resulting two liquid phases were separated, and the aqueous layer was extracted with $\mathrm{CHCl}_{3}(3 \times 15 \mathrm{~mL})$. The combined organic layers were dried over $\mathrm{MgSO}_{4}$, filtered, and evaporated in vacuo. The crude product was purified by column chromatography (silica gel; mobile phase: $\mathrm{CHCl}_{3}$ ) and dried for $4 \mathrm{~h}$ at room temperature under dynamic vacuum. Yield: $602 \mathrm{mg}(76 \%)$. Single crystals of $\mathbf{7}$ that were suitable for X-ray diffraction were obtained by gas-phase diffusion of hexane into a toluene solution of $7 . R_{\mathrm{f}}=0.37$ $\left(\mathrm{CHCl}_{3}\right) ;{ }^{1} \mathrm{H}$ NMR $\left(300.0 \mathrm{MHz}, \mathrm{C}_{6} \mathrm{D}_{6}\right): \delta=2.16\left(\mathrm{~s}, 12 \mathrm{H} ; o-\mathrm{CH}_{3}\right), 2.35(\mathrm{~s}$, $\left.6 \mathrm{H} ; p-\mathrm{CH}_{3}\right), 6.93$ (s, 4H; MesH-3,5), 7.10 (app. td, ${ }^{3} J(\mathrm{H}, \mathrm{H})=7.4 \mathrm{~Hz},{ }^{4} J-$ 
$(\mathrm{H}, \mathrm{H})=1.4 \mathrm{~Hz}, 4 \mathrm{H}$; H-2,7 or H-3,6), 7.15 (app. td, ${ }^{3} J(\mathrm{H}, \mathrm{H})=7.4 \mathrm{~Hz},{ }^{4} J-$ $(\mathrm{H}, \mathrm{H})=1.4 \mathrm{~Hz}, 4 \mathrm{H} ; \mathrm{H}-2,7$ or $\mathrm{H}-3,6), 7.86\left(\mathrm{dd},{ }^{3} J(\mathrm{H}, \mathrm{H})=7.0 \mathrm{~Hz},{ }^{4} J-\right.$ $(\mathrm{H}, \mathrm{H})=1.4 \mathrm{~Hz}, 4 \mathrm{H} ; \mathrm{H}-1,8$ or $\mathrm{H}-4,5), 7.98 \mathrm{ppm}\left(\mathrm{dd},{ }^{3} J(\mathrm{H}, \mathrm{H})=7.0 \mathrm{~Hz},{ }^{4} J-\right.$ $(\mathrm{H}, \mathrm{H})=1.4 \mathrm{~Hz}, 4 \mathrm{H} ; \mathrm{H}-1,8$ or $\mathrm{H}-4,5) ;{ }^{11} \mathrm{~B}\left\{{ }^{1} \mathrm{H}\right\} \mathrm{NMR}\left(96.3 \mathrm{MHz}, \mathrm{C}_{6} \mathrm{D}_{6}\right)$ : $\delta=43.9 \quad\left(h_{1 / 2}=1500 \mathrm{~Hz} ; \quad \mathrm{BO}\right), \quad 70.2 \mathrm{ppm} \quad(\mathrm{br} ; \quad \mathrm{BMes}) ;{ }^{13} \mathrm{C}\left\{{ }^{1} \mathrm{H}\right\} \mathrm{NMR}$ $\left(75.5 \mathrm{MHz}, \mathrm{C}_{6} \mathrm{D}_{6}\right): \delta=21.4\left(p-\mathrm{CH}_{3}\right), 22.9\left(o-\mathrm{CH}_{3}\right), 127.6(\mathrm{MesC}-3,5)$, 132.8 (C-2,7 or C-3,6), 133.6 (C-2,7 or C-3,6), 133.8 (C-1,8 or C-4,5), 137.0 (MesC-4), 138.1 (MesC-2,6), 139.6 ppm (C-1,8 or C-4,5), n.o. (BC); elemental analysis calcd (\%) for $\mathrm{C}_{42} \mathrm{H}_{38} \mathrm{~B}_{4} \mathrm{O}$ (601.99): C 83.80, H 6.36; found: C 83.53, H 6.54 .

Synthesis of 10: Neat $\mathrm{BBr}_{3}(32 \mu \mathrm{L}, 83.2 \mathrm{mg}, 0.33 \mathrm{mmol})$ was added at room temperature to $7(50 \mathrm{mg}, 0.08 \mathrm{mmol})$ in $\mathrm{C}_{6} \mathrm{H}_{6}(2 \mathrm{~mL})$. After the solution had been kept at room temperature for $31 \mathrm{~h}$, all volatiles were removed under reduced pressure over a period of $12 \mathrm{~h}$. The yellow solid residue was treated with $\mathrm{C}_{6} \mathrm{H}_{6}(2 \mathrm{~mL})$ and the resulting solution was separated from small amounts of a colorless solid by using a syringe. After evaporation to dryness under reduced pressure, $\mathbf{1 0}$ was obtained as a yellow solid. Yield: $46.7 \mathrm{mg}$ ( $75 \%)$. Single crystals of $\mathbf{1 0}$ were grown by slow evaporation of the reaction mixture. ${ }^{1} \mathrm{H}$ NMR $\left(250.1 \mathrm{MHz}, \mathrm{C}_{6} \mathrm{D}_{6}\right)$ : $\delta=1.96\left(\mathrm{~s}, 6 \mathrm{H} ; o-\mathrm{CH}_{3}\right), 2.30\left(\mathrm{~s}, 3 \mathrm{H} ; p-\mathrm{CH}_{3}\right), 6.86(\mathrm{~m}, 2 \mathrm{H} ; \mathrm{MesH}-3,5)$, 7.09 (app. td, ${ }^{3} J(\mathrm{H}, \mathrm{H})=7.3 \mathrm{~Hz},{ }^{4} J(\mathrm{H}, \mathrm{H})=1.4 \mathrm{~Hz}, 2 \mathrm{H} ; \mathrm{H}-2,7$ or $\left.\mathrm{H}-3,6\right)$, 7.19 (app. td, ${ }^{3} J(\mathrm{H}, \mathrm{H})=7.3 \mathrm{~Hz},{ }^{4} J(\mathrm{H}, \mathrm{H})=1.4 \mathrm{~Hz}, 2 \mathrm{H} ; 2,7$ or $\left.\mathrm{H}-3,6\right), 7.61$ $\left(\mathrm{dd},{ }^{3} J(\mathrm{H}, \mathrm{H})=7.3 \mathrm{~Hz},{ }^{4} J(\mathrm{H}, \mathrm{H})=1.4 \mathrm{~Hz}, 2 \mathrm{H} ; \mathrm{H}-1,8\right.$ or $\left.\mathrm{H}-4,5\right), 8.52 \mathrm{ppm}$ (dd, ${ }^{3} J(\mathrm{H}, \mathrm{H})=7.3 \mathrm{~Hz}, \quad{ }^{4} J(\mathrm{H}, \mathrm{H})=1.4 \mathrm{~Hz}, \quad 2 \mathrm{H} ; \quad \mathrm{H}-1,8 \quad$ or $\left.\mathrm{H}-4,5\right)$; ${ }^{11} \mathrm{~B}\left\{{ }^{1} \mathrm{H}\right\} \mathrm{NMR} \quad\left(96.3 \mathrm{MHz}, \quad \mathrm{C}_{6} \mathrm{D}_{6}\right): \quad \delta=65.0, \quad 69.4 \mathrm{ppm} \quad(\mathrm{BBr}, \quad \mathrm{BMes})$; $\left.{ }^{13} \mathrm{C}{ }^{1} \mathrm{H}\right\} \mathrm{NMR}\left(62.9 \mathrm{MHz}, \mathrm{C}_{6} \mathrm{D}_{6}\right): \delta=21.4\left(p-\mathrm{CH}_{3}\right), 22.6\left(o-\mathrm{CH}_{3}\right), 127.6$ (MesC-3,5), 133.9 (C-2,7 or C-3,6), 134.5 (C-2,7 or C-3,6), 137.2 (MesC4), 138.0 (MesC-2,6), 139.0 (C-1,8 or C-4,5), 139.3 ppm (C-1,8 or C-4,5), n.o. (BC).

Synthesis of 11: Compound $\mathbf{1 0}(18.6 \mathrm{mg}, 0.05 \mathrm{mmol})$ in $\mathrm{C}_{6} \mathrm{H}_{6}(0.5 \mathrm{~mL})$ was added at room temperature to a solution of 2,2'-bipyridyl $(10.4 \mathrm{mg}$, $0.07 \mathrm{mmol})$ in toluene $(0.1 \mathrm{~mL})$, whereupon a yellow solid precipitated immediately. The solution was removed by using a syringe and discarded; the precipitate was washed with toluene $(2 \times 1.5 \mathrm{~mL})$ and dried under dynamic vacuum. [MesB $\left(\mathrm{C}_{6} \mathrm{H}_{4}\right)_{2} \mathrm{~B}$ (bipy)] Br was dissolved in $\mathrm{MeOH}(2 \mathrm{~mL})$ and treated with an aqueous solution of $\mathrm{NH}_{4} \mathrm{PF}_{6}(0.20 \mathrm{M}, 1.0 \mathrm{~mL}$, $0.20 \mathrm{mmol}$ ), whereupon a yellow precipitate formed. The solid product was isolated by decanting the supernatant after centrifugation, washed with deionized $\mathrm{H}_{2} \mathrm{O}(2 \mathrm{~mL})$, and dried under vacuum. Single crystals that were suitable for $\mathrm{X}$-ray diffraction were obtained by gas-phase diffusion of $\mathrm{Et}_{2} \mathrm{O}$ into a $\mathrm{CH}_{3} \mathrm{CN}$ solution of 11. Yield: $15.2 \mathrm{mg}$ (51\%; crystalline material). ${ }^{1} \mathrm{H}$ NMR $\left(300.0 \mathrm{MHz}, \mathrm{CD}_{3} \mathrm{CN}\right): \delta=2.12\left(\mathrm{~s}, 6 \mathrm{H} ; o-\mathrm{CH}_{3}\right), 2.40$ $\left(\mathrm{s}, 3 \mathrm{H} ; p-\mathrm{CH}_{3}\right), 6.66\left(\mathrm{dm},{ }^{3} \mathrm{~J}(\mathrm{H}, \mathrm{H})=7.0 \mathrm{~Hz}, 2 \mathrm{H} ; \mathrm{H}-1,8\right.$ or $\left.\mathrm{H}-4,5\right), 7.00(\mathrm{~m}$, $2 \mathrm{H}$; MesH-3,5), 7.32 (app. td, ${ }^{3} J(\mathrm{H}, \mathrm{H})=7.3 \mathrm{~Hz},{ }^{4} J(\mathrm{H}, \mathrm{H})=1.6 \mathrm{~Hz}, 2 \mathrm{H} ; \mathrm{H}$ $2,7$ or $\mathrm{H}-3,6), 7.36$ (app. td, ${ }^{3} J(\mathrm{H}, \mathrm{H})=7.3 \mathrm{~Hz},{ }^{4} J(\mathrm{H}, \mathrm{H})=1.6 \mathrm{~Hz}, 2 \mathrm{H}$; H$2,7$ or $\mathrm{H}-3,6), 7.63\left(\mathrm{dm},{ }^{3} J(\mathrm{H}, \mathrm{H})=7.0 \mathrm{~Hz}, 2 \mathrm{H}\right.$; H-1,8 or H-4,5), 7.95 (ddd, ${ }^{3} J(\mathrm{H}, \mathrm{H})=7.7 \mathrm{~Hz},{ }^{3} J(\mathrm{H}, \mathrm{H})=5.7 \mathrm{~Hz},{ }^{4} J(\mathrm{H}, \mathrm{H})=1.2 \mathrm{~Hz}, 2 \mathrm{H}$; bipyH-5,5'), $8.29\left(\mathrm{ddd},{ }^{3} J(\mathrm{H}, \mathrm{H})=5.7 \mathrm{~Hz},{ }^{4} J(\mathrm{H}, \mathrm{H})=1.3 \mathrm{~Hz},{ }^{5} J(\mathrm{H}, \mathrm{H})=0.9 \mathrm{~Hz}, \quad 2 \mathrm{H}\right.$; bipyH-6,6 $), 8.67\left(\mathrm{ddd},{ }^{3} J(\mathrm{H}, \mathrm{H})=8.1 \mathrm{~Hz},{ }^{3} J(\mathrm{H}, \mathrm{H})=7.7 \mathrm{~Hz},{ }^{4} J(\mathrm{H}, \mathrm{H})=\right.$ $1.3 \mathrm{~Hz}, 2 \mathrm{H}$; bipyH-4,4'), $8.89 \mathrm{ppm}\left(\mathrm{d}\right.$ app. $\mathrm{t},{ }^{3} \mathrm{~J}(\mathrm{H}, \mathrm{H})=8.1 \mathrm{~Hz},{ }^{4} J(\mathrm{H}, \mathrm{H})=$ ${ }^{5} J(\mathrm{H}, \mathrm{H})=1.1 \mathrm{~Hz}, 2 \mathrm{H} ;$ bipyH-3,3'); ${ }^{11} \mathrm{~B}\left\{{ }^{1} \mathrm{H}\right\} \mathrm{NMR}\left(96.3 \mathrm{MHz}, \mathrm{CD}_{3} \mathrm{CN}\right)$ : $\delta=5.5 \quad\left(h_{1 / 2}=250 \mathrm{~Hz} ; \quad\right.$ B-bipy $), \quad 69.5 \mathrm{ppm} \quad\left(h_{1 / 2}=1000 \mathrm{~Hz} ; \quad\right.$ BMes $)$; ${ }^{13} \mathrm{C}\left\{{ }^{1} \mathrm{H}\right\} \mathrm{NMR} \quad\left(100.6 \mathrm{MHz}, \quad \mathrm{CD}_{3} \mathrm{CN}\right): \delta=21.3 \quad\left(p-\mathrm{CH}_{3}\right), 23.0 \quad\left(o-\mathrm{CH}_{3}\right)$, 124.5 (bipyC-3,3'), 127.8 (MesC-3,5), 129.9 (C-2,7 or C-3,6), 130.5 (bipyC5,5') 131.9 (C-1,8 or C-4,5), 134.5 (C-2,7 or C-3,6), 137.8 (MesC-4), 138.7 (MesC-2,6), 139.7 (C-1,8 or C-4,5), 144.3 (bipyC-6,6'), 146.0 (bipyC-4,4'), 147.6 ppm (bipyC-2,2'), n.o. (BC); $\mathrm{MS}\left(\mathrm{ESI}^{+}\right): \mathrm{m} / z$ (\%): 450 (100) [M-$\left.\left(\mathrm{PF}_{6}\right)\right]^{+}$; elemental analysis calcd $(\%)$ for $\mathrm{C}_{31} \mathrm{H}_{27} \mathrm{~B}_{2} \mathrm{~F}_{6} \mathrm{~N}_{2} \mathrm{P}$ (594.14): $\mathrm{C}$ 62.67, H 4.58, N 4.71; found: C 62.02, H 4.55, N 4.45.

Synthesis of $(\mathbf{9})_{2}$ : Excess neat $\mathrm{Et}_{3} \mathrm{SiH}(1 \mathrm{~mL}, 728 \mathrm{mg}, 6.26 \mathrm{mmol})$ was added at room temperature to neat $\mathbf{1 0}(64.9 \mathrm{mg}, 0.17 \mathrm{mmol})$. The resulting mixture was stored without stirring at room temperature for 1 day, whereupon pale-yellow crystals formed. The mother liquor was removed by using a syringe and the crystalline product $(\mathbf{9})_{2}$ was dried under vacuum. Yield: $35.6 \mathrm{mg} \quad(70 \%)$. IR $\left(\mathrm{C}_{6} \mathrm{H}_{6}\right): \tilde{v}=2481 \mathrm{~cm}^{-1} \quad(\mathrm{~B}-\mathrm{H})$. ${ }^{1} \mathrm{H}$ NMR $\left(400.1 \mathrm{MHz}, \mathrm{C}_{6} \mathrm{D}_{6}\right): \delta=2.03\left(\mathrm{~s}, 6 \mathrm{H} ; o-\mathrm{CH}_{3}\right), 2.32(\mathrm{~s}, 3 \mathrm{H} ; p$ $\left.\mathrm{CH}_{3}\right), 6.89$ (s, 2 H; MesH-3,5), 7.12 (app. td, ${ }^{3} J(\mathrm{H}, \mathrm{H})=7.4 \mathrm{~Hz},{ }^{4} J(\mathrm{H}, \mathrm{H})=$ $1.4 \mathrm{~Hz}, 2 \mathrm{H}$; H-2,7 or $\mathrm{H}-3,6), 7.22$ (app. td, ${ }^{3} J(\mathrm{H}, \mathrm{H})=7.4 \mathrm{~Hz},{ }^{4} J(\mathrm{H}, \mathrm{H})=$
$1.4 \mathrm{~Hz}, 2 \mathrm{H}$; H-2,7 or H-3,6), $7.67\left(\mathrm{~d},{ }^{3} J(\mathrm{H}, \mathrm{H})=7.4 \mathrm{~Hz}, 2 \mathrm{H}\right.$; H-1,8 or H4,5), $7.93 \mathrm{ppm}\left(\mathrm{d},{ }^{3} J(\mathrm{H}, \mathrm{H})=7.4 \mathrm{~Hz}, 2 \mathrm{H} ; \mathrm{H}-1,8\right.$ or $\left.\mathrm{H}-4,5\right) ;{ }^{11} \mathrm{~B}$ NMR $\left(128.4 \mathrm{MHz}, \quad \mathrm{C}_{6} \mathrm{D}_{6}\right): \quad \delta=71.0 \mathrm{ppm} \quad\left(h_{1 / 2}=1500 \mathrm{~Hz} ; \quad\right.$ BMes, $\left.\mathrm{BH}\right)$; ${ }^{13} \mathrm{C}\left\{{ }^{1} \mathrm{H}\right\}$ NMR $\left(75.5 \mathrm{MHz}, \mathrm{C}_{6} \mathrm{D}_{6}\right): \delta=21.4\left(p-\mathrm{CH}_{3}\right), 22.7\left(o-\mathrm{CH}_{3}\right), 127.5$ (MesC-3,5), 133.7 (C-2,7 or C-3,6), 134.2 (C-2,7 or C-3,6), 137.0 (MesC4), 138.0 (MesC-2,6), 139.0 (C-1,8 or C-4,5), 142.0 ppm (C-1,8 or C-4,5), n.o. (BC); elemental analysis calcd (\%) for $\mathrm{C}_{42} \mathrm{H}_{40} \mathrm{~B}_{4}$ (587.98): $\mathrm{C} 85.80, \mathrm{H}$ 6.86; found: C 85.13, H 6.77 .

Synthesis of 14: Neat $\mathrm{MesC} \equiv \mathrm{CH}(51.3 \mu \mathrm{L}, 47.7 \mathrm{mg}, 0.331 \mathrm{mmol})$ was added at room temperature to $9 \cdot \mathrm{THF}(121 \mathrm{mg}, 0.331 \mathrm{mmol})$ in $\mathrm{C}_{6} \mathrm{H}_{6}$ $(7 \mathrm{~mL})$ by using a Hamilton syringe, and the reaction mixture was stirred for $1 \mathrm{~h}$. All volatiles were removed under reduced pressure, the yellow solid residue was treated with hexane $(5 \mathrm{~mL})$, and the insoluble material was collected on a frit and extracted into hexane $(2 \times 1 \mathrm{~mL})$. The combined hexane solutions were evaporated to dryness in vacuo to obtain a yellow microcrystalline solid of $\mathbf{1 4}$ and $\left[\mathrm{AlCl}_{3}(\mathrm{THF})_{2}\right]$. The two components were separated from each other by fractional crystallization from hexane at $4{ }^{\circ} \mathrm{C}\left(\left[\mathrm{AlCl}_{3}(\mathrm{THF})_{2}\right]\right)$ and $-30^{\circ} \mathrm{C}(\mathbf{1 4})$. Single crystals of 14 that were suitable for $\mathrm{X}$-ray diffraction were grown by slow evaporation of a pentane $/ \mathrm{C}_{6} \mathrm{H}_{6}$ solution $(50: 1)$ at room temperature. The yields of $\mathbf{1 4}$ reproducibly ranged between $20-30 \%$; yields of $\mathbf{1 4}$ close to $90 \%$ were obtained under similar conditions with $\mathbf{9}$ as the hydroboration reagent ${ }^{1} \mathrm{H}$ NMR (400.1 MHz, $\left.\mathrm{C}_{6} \mathrm{D}_{6}\right): \delta=2.08\left(\mathrm{~s}, 6 \mathrm{H} ; o-\mathrm{CH}_{3}\right), 2.17(\mathrm{~s}, 3 \mathrm{H} ; p$ $\left.\mathrm{CH}_{3}{ }^{\prime}\right), 2.32\left(\mathrm{~s}, 6 \mathrm{H} ; o-\mathrm{CH}_{3}{ }^{\prime}\right), 2.33\left(\mathrm{~s}, 3 \mathrm{H} ; p-\mathrm{CH}_{3}\right), 6.83\left(\mathrm{~s}, 2 \mathrm{H} ; \mathrm{MesH}-3,5^{\prime}\right)$ 6.91 (s, 2 H; MesH-3,5), 7.21 (app. td, ${ }^{3} J(\mathrm{H}, \mathrm{H})=7.3 \mathrm{~Hz},{ }^{4} J(\mathrm{H}, \mathrm{H})=1.3 \mathrm{~Hz}$, $2 \mathrm{H}$; H-2,7), 7.32 (app. td, $\left.{ }^{3} J(\mathrm{H}, \mathrm{H})=7.3 \mathrm{~Hz},{ }^{4} J(\mathrm{H}, \mathrm{H})=1.3 \mathrm{~Hz}, 2 \mathrm{H} ; \mathrm{H}-3,6\right)$ $7.34\left(\mathrm{~d},{ }^{3} J(\mathrm{H}, \mathrm{H})=18.8 \mathrm{~Hz}, 1 \mathrm{H} ; \quad \mathrm{BC}(H)=\mathrm{C}(\mathrm{H})\right), 7.52\left(\mathrm{~d},{ }^{3} J(\mathrm{H}, \mathrm{H})=\right.$ $18.8 \mathrm{~Hz}, 1 \mathrm{H} ; \mathrm{BC}(\mathrm{H})=\mathrm{C}(H)), 7.82\left(\mathrm{~d},{ }^{3} \mathrm{~J}(\mathrm{H}, \mathrm{H})=7.3 \mathrm{~Hz}, 2 \mathrm{H} ; \mathrm{H}-1,8\right)$, $8.24 \mathrm{ppm}\left(\mathrm{d},{ }^{3} J(\mathrm{H}, \mathrm{H})=7.3 \mathrm{~Hz}, 2 \mathrm{H} ; \mathrm{H}-4,5\right) ;{ }^{11} \mathrm{~B}\left\{{ }^{1} \mathrm{H}\right\} \mathrm{NMR}(128.4 \mathrm{MHz}$ $\mathrm{C}_{6} \mathrm{D}_{6}$ ): $\delta=71.6 \mathrm{ppm}$ (shoulder at $\delta=62.8 \mathrm{ppm}$; $\mathrm{BMes}, \mathrm{BC}(\mathrm{H})=\mathrm{C}(\mathrm{H})$ ); ${ }^{13} \mathrm{C}\left\{{ }^{1} \mathrm{H}\right\}$ NMR $\left(100.6 \mathrm{MHz}, \mathrm{C}_{6} \mathrm{D}_{6}\right): \delta=21.1\left(p-\mathrm{CH}_{3}{ }^{\prime}\right), 21.3\left(o-\mathrm{CH}_{3}{ }^{\prime}\right), 21.4$ $\left(p-\mathrm{CH}_{3}\right), 22.8\left(o-\mathrm{CH}_{3}\right), 127.5(\mathrm{MesC}-3,5), 129.4$ (MesC-3,5'), 133.0 (C2,7), 133.2 (C-3,6), 136.1 (MesC-2,6' $), 136.5$ (MesC-1'), 136.8 (MesC-4), 137.0 (MesC-4'), 137.5 (C-4,5), 138.1 (MesC-2,6), 138.6 (br; $\mathrm{BC}(\mathrm{H})=$ $\mathrm{C}(\mathrm{H})$ ), 139.6 (C-1,8), 141.5 (br; MesC-1), 145.7 (br; $\left.\mathrm{C}_{6} \mathrm{H}_{4}-\mathrm{BC}\right), 147.5$ (br; $\left.\mathrm{C}_{6} \mathrm{H}_{4}-\mathrm{BC}\right), 149.6 \mathrm{ppm}(\mathrm{BC}(\mathrm{H})=C(\mathrm{H}))$; elemental analysis calcd $(\%)$ for $\mathrm{C}_{32} \mathrm{H}_{32} \mathrm{~B}_{2}$ (438.20): C 87.71, H 7.36; found: C 87.39, H 7.35. Note: Resonances belonging to the 2-mesitylethenyl substituent are marked with a prime $\left({ }^{\prime}\right)$.

Crystal structure analyses: All crystals except those of $\mathrm{HOB}\left(\mathrm{C}_{6} \mathrm{H}_{4}\right)_{2} \mathrm{BOH}$ were measured on a STOE IPDS-II diffractometer with graphite-monochromated $\mathrm{Mo}_{\mathrm{K} \alpha}$ radiation. An empirical absorption correction with program PLATON ${ }^{[34]}$ was performed for $\mathbf{2}, \mathbf{6}$, and $\mathbf{1 0}$. The structures were solved by direct methods ${ }^{[35]}$ and refined with full-matrix least-squares on $F^{2}$ using the program SHELXL97. ${ }^{[36]}$ The hydrogen atoms bonded to boron in $\mathbf{8}, \mathbf{9} \cdot \mathrm{THF}$, and $(\mathbf{9})_{2}$ were isotropically refined. All other hydrogen atoms were placed in ideal positions and refined with fixed isotropic displacement parameters using a riding model.

One sulfur atom and one methyl group of $\mathbf{2}$ are disordered over two positions with a site occupation factor of $0.656(8)$ for the major occupied site. The crystal of 6 was a non-merohedral twin with a fraction of $0.576(6)$ for the major domain. The hydrogen atoms of three methyl groups of 7 are disordered over two positions with equally occupied sites. In 11, the para-methyl group of the mesityl ring is disordered over two equally occupied positions. In one of the two crystallographically independent molecules of $\mathbf{1 4}$ (i.e., $\mathbf{1 4}_{\mathbf{B}}$ ), the atoms of the $\mathrm{C}=\mathrm{C}$ double bond are disordered over two positions with a site occupation factor of $0.58(2)$ for the major occupied site. Bond lengths and angles involving the disordered atoms were restrained to be equal to those in the non-disordered molecule.

$\mathrm{HOB}\left(\mathrm{C}_{6} \mathrm{H}_{4}\right)_{2} \mathrm{BOH}$ was measured with a Siemens SMART diffractometer. No absorption correction was made. The structure was determined by direct methods ${ }^{[35]}$ and refined with full-matrix least-squares on $F^{2}$ using the program SHELXL97. ${ }^{[36]}$ The hydrogen atoms were geometrically positioned and were constrained. The crystal was twinned, the twin relations are: $h^{\prime}=-h, k^{\prime}=-k$, and $l^{\prime}=0.895 h+1$, the twin fraction refined to $0.302(7)$.

CCDC-824867 (ClB $\left.\left(\mathrm{C}_{6} \mathrm{H}_{4}\right)_{2} \mathrm{BCl}\right), \quad \mathrm{CCDC}-824869 \quad\left(\mathrm{HOB}\left(\mathrm{C}_{6} \mathrm{H}_{4}\right)_{2} \mathrm{BOH}\right)$ CCDC-824870 (2), CCDC-824868 (6), CCDC-824871 (7), CCDC-824872 
(8), CCDC-824873 (9-THF), CCDC-826346 ((9) $\left.)_{2}\right)$, CCDC-826345 (10), CCDC-824875 (11), and CCDC-824874 (14) contain the supplementary crystallographic data for this paper.

\section{Acknowledgements}

M. W. acknowledges financial support by the Beilstein-Institut, Frankfurt/Main, Germany, within the research collaboration NanoBiC. A. L. wishes to thank the Fonds der Chemischen Industrie for a PhD grant.

[1] C. D. Entwistle, T. B. Marder, Angew. Chem. 2002, 114, 3051-3056; Angew. Chem. Int. Ed. 2002, 41, 2927-2931.

[2] C. D. Entwistle, T. B. Marder, Chem. Mater. 2004, 16, 4574-4585.

[3] S. Yamaguchi, A. Wakamiya, Pure Appl. Chem. 2006, 78, 14131424.

[4] F. Jäkle, Chem. Rev. 2010, 110, 3985-4022.

[5] F. Jäkle, Coord. Chem. Rev. 2006, 250, 1107-1121.

[6] T. W. Hudnall, C.-W. Chiu, F. P. Gabbaï, Acc. Chem. Res. 2009, 42, 388-397.

[7] C. R. Wade, A. E. J. Broomsgrove, S. Aldridge, F. P. Gabbaï, Chem. Rev. 2010, 110, 3958-3984.

[8] For selected references that have not been covered by the earlier reviews cited above, see: a) A. Wakamiya, T. Taniguchi, S. Yamaguchi, Angew. Chem. 2006, 118, 3242-3245; Angew. Chem. Int. Ed. 2006, 45, 3170-3173; b) H. Li, F. Jäkle, Macromol. Rapid Commun. 2010, 31, 915-920; c) H. Li, A. Sundararaman, T. Pakkirisamy, K. Venkatasubbaiah, F. Schödel, F. Jäkle, Macromolecules 2011, 44, 95-103; d) Z. M. Hudson, X.-Y. Liu, S. Wang, Org. Lett. 2011, 13, 300-303; e) Z. M. Hudson, M. G. Helander, Z.-H. Lu, S. Wang, Chem. Commun. 2011, 47, 755-757; f) C. Sun, J. Lu, S. Wang, Org. Lett. 2011, 13, 1226-1229; g) C. Baik, S. K. Murphy, S. Wang, Angew. Chem. 2010, 122, 8400-8403; Angew. Chem. Int. Ed. 2010, 49, 82248227; h) E. Sakuda, Y. Ando, A. Ito, N. Kitamura, Inorg. Chem. 2011, 50, 1603-1613; i) Y. Kim, H.-S. Huh, M. H. Lee, I. L. Lenov, H. Zhao, F. P. Gabbaï, Chem. Eur. J. 2011, 17, 2057-2062; j) C. Bresner, C. J. E. Haynes, D. A. Addy, A. E. J. Broomsgrove, P. Fitzpatrick, D. Vidovic, A. L. Thompson, I. A. Fallis, S. Aldridge, New J. Chem. 2010, 34, 1652-1659.

[9] W. Schacht, D. Kaufmann, J. Organomet. Chem. 1987, 331, 139-152.

[10] J. J. Eisch, B. W. Kotowicz, Eur. J. Inorg. Chem. 1998, 761-769.

[11] S. Bieller, F. Zhang, M. Bolte, J. W. Bats, H.-W. Lerner, M. Wagner, Organometallics 2004, 23, 2107-2113.

[12] A. Lorbach, C. Reus, M. Bolte, H.-W. Lerner, M. Wagner, Adv. Synth. Catal. 2010, 352, 3443-3449.

[13] A. Lorbach, M. Bolte, H. Li, H.-W. Lerner, M. C. Holthausen, F. Jäkle, M. Wagner, Angew. Chem. 2009, 121, 4654-4658; Angew. Chem. Int. Ed. 2009, 48, 4584-4588.
[14] A. Lorbach, M. Bolte, H.-W. Lerner, M. Wagner, Chem. Commun. 2010, 46, 3592-3594.

[15] A. Lorbach, Ph. D. Thesis, Goethe-Universität Frankfurt, Frankfurt (Germany), 2011.

[16] A. Lorbach, M. Bolte, H.-W. Lerner, M. Wagner, Organometallics 2010, 29, 5762-5765.

[17] A. Hübner, Z.-W. Qu, U. Englert, M. Bolte, H.-W. Lerner, M. C. Holthausen, M. Wagner, J. Am. Chem. Soc. 2011, 133, 4596-4609.

[18] T. Agou, M. Sekine, T. Kawashima, Tetrahedron Lett. 2010, 51, 5013-5015.

[19] T. Lange, U. Böhme, G. Roewer, Inorg. Chem. Commun. 2002, 5, $377-379$.

[20] L. Kaufmann, H.-W. Lerner, M. Bolte, Acta Crystallogr. C 2007, 63, o588-0590.

[21] H. Nöth, B. Wrackmeyer, Nuclear Magnetic Resonance Spectroscopy of Boron Compounds, in NMR Basic Principles and Progress (Eds. P. Diehl, E. Fluck, R. Kosfeld), Springer, Berlin, 1978.

[22] See reference [11]; note: An improved synthetic protocol for $\mathbf{6}$ together with a full NMR spectroscopic and structural characterization is reported in the Supporting Information of this paper.

[23] H. Eriksson, M. Håkansson, Organometallics 1997, 16, 4243-4244.

[24] J. F. W. McOmie, D. E. West, Org. Synth. Coll. Vol. 5, 1973. 412.

[25] F. Fabrizi de Biani, T. Gmeinwieser, E. Herdtweck, F. Jäkle, F. Laschi, M. Wagner, P. Zanello, Organometallics 1997, 16, 47764787.

[26] D. J. Parks, W. E. Piers, G. P. A. Yap, Organometallics 1998, 17, $5492-5503$.

[27] R. A. Bartlett, H. V. R. Dias, M. M. Olmstead, P. P. Power, K. J. Weese, Organometallics 1990, 9, 146-150.

[28] E. Negishi, J.-J. Katz, H. C. Brown, J. Am. Chem. Soc. 1972, 94 , $4025-4027$.

[29] K. Ishihara, J. Kobayashi, K. Nakano, H. Ishibashi, H. Yamamoto, Chirality 2003, 15, 135-138.

[30] Z. Yuan, C. D. Entwistle, J. C. Collings, D. Albesa-Jové, A. S. Batsanov, J. A. K. Howard, N. J. Taylor, H. M. Kaiser, D. E. Kaufmann, S.-Y. Poon, W.-Y. Wong, C. Jardin, S. Fathallah, A. Boucekkine, J.-F. Halet, T. B. Marder, Chem. Eur. J. 2006, 12, 2758-2771.

[31] V. Leen, W. Qin, W. Yang, J. Cui, C. Xu, X. Tang, W. Liu, K. Robeyns, L. Van Meervelt, D. Beljonne, R. Lazzaroni, C. Tonnelé, N. Boens, W. Dehaen, Chem. Asian J. 2010, 5, 2016-2026.

[32] R. Clément, Compt. Rend. Acad. Sci. Paris 1965, 261, 4436-4438.

[33] A. Pelter, S. Singaram, H. Brown, Tetrahedron Lett. 1983, 24, 14331436.

[34] A. L. Spek, J. Appl. Crystallogr. 2003, 36, 7-13.

[35] G. M. Sheldrick, Acta Crystallogr. A 1990, 46, 467-473.

[36] G. M. Sheldrick, SHELXL-97. A Program for the Refinement of Crystal Structures, Universität Göttingen, Göttingen (Germany), 1997. 